\title{
Role of Multifunctional Autonomously Replicating Sequence Binding Factor 1 in the Initiation of DNA Replication and Transcriptional Control in Saccharomyces cerevisiae
}

\author{
PETER R. RHODE, $\uparrow$ SUZANNE ELSASSER, AND JUDITH L. CAMPBELL* \\ Braun Laboratories 147-75, California Institute of Technology, Pasadena, California 91125
}

Received 22 August 1991/Accepted 22 November 1991

\begin{abstract}
Autonomously replicating sequence (ARS) binding factor 1 (ABF1) is an abundant DNA-binding protein that specifically recognizes the motif RTCRYN ${ }_{5} A C G$ at many sites in the yeast genome, including promoter elements, mating-type silencers, and ARSs. Mutational analysis of these sites suggests that ABF1 is involved in constitutive and carbon source-regulated transcriptional activation, transcriptional silencing, and ARS activity. To better assess the role of ABF1 in DNA replication and transcriptional control, temperaturesensitive lethal mutations in the $A B F 1$ gene were isolated. Several of the abf1(Ts) strains show rapid growth arrest at the nonpermissive temperature. At the semipermissive temperature, these strains show an ARSspecific defect in the mitotic stability of $A R S-C E N$ plasmids, such that the abf1 mutants show defects in ARS function identical to those of mutants bearing the mutations in the cis-acting ABF1 binding sites analyzed previously by numerous investigators. Flow cytometric analysis and in vivo DNA labeling experiments on an $\alpha$-factor synchronized $a b f 1(T s)$ strain showed that at the nonpermissive temperature, these cells fail to progress eficiently from $G_{1}$ through $S$ phase and synthesize DNA at $25 \%$ of the level seen in the isogenic $A B F 1$ strain. RNA synthesis is also reduced in the abf1(Ts) strains. In addition, transcriptional activation by an ABF1 binding site upstream activation sequence is completely defective in an abf1(Ts) strain at the semipermissive temperature. These phenotypes provide evidence that the same protein, ABF1, functions in the initiation of DNA replication and transcriptional activation.
\end{abstract}

The initiation of DNA replication requires the concerted action of many proteins at discrete replication origins along each chromosome. In prokaryotic and viral replicons, a sequence-specific DNA-binding protein called the initiator interacts with and unwinds the origin region prior to the initiation of bidirectional replication by the DNA polymerase-primase complex. In many cases, auxiliary DNA-binding proteins are also required for efficient origin activity (see reference 23 for a review). Current efforts have focused on characterizing similar initiation factors and their mechanisms of action in eukaryotic chromosomal replication, whereby multiple origins initiate in a specific temporal pattern during the $\mathbf{S}$ phase of the cell cycle.

In the yeast Saccharomyces cerevisiae, origins of DNA replication were initially characterized as autonomously replicating sequences (ARSs) by their ability to act in cis to allow extrachromosomal maintenance of plasmid DNA. Direct evidence that a subset of ARSs (though not all) function as chromosomal origins has come from two-dimensional gel analysis of replication intermediates $(5,40,41)$. Sequence requirements for origin function in plasmids and in the chromosome reveal that yeast ARSs are complex (see reference 14 for a review). Comparison of more than 20 ARSs identified two common features: high $\mathrm{A}+\mathrm{T}$ content and a common consensus sequence (WTTTATRTTTW, where W is $A$ or $T$ and $R$ is $A$ or $G$ ), referred to as domain $A(7)$. Mutational analysis of domain $A$ has shown that it is essential but not sufficient in most contexts for plasmid ARS function $(15,45)$. In addition, sequences (referred to as domain B) $3^{\prime}$ to the T-rich strand of the core consensus

\footnotetext{
* Corresponding author.

$\dagger$ Present address: Baxter Diagnostics Inc.-Pandex, Mundelein, IL 60060 .
}

contain multiple functionally redundant elements that are required for ARS activity. The nature of these elements varies between different ARSs and may include close matches to the core consensus (56), specific protein recognition sites $(8,24,29,62,68)$, and sequences that allow DNA bending $(69,75)$ or melting $(71)$. By analogy to prokaryotic and viral systems, these findings suggest that initiator and auxiliary proteins interact with the core consensus and domain B elements, respectively, to facilitate DNA unwinding prior to the initiation of DNA replication.

A number of proteins that bind to ARS elements have been characterized $(8,24,29,39,60,62,68,72)$. Recently, single-stranded-DNA-binding proteins, ACBP (39) and ssARS-T (60), have been identified on the basis of specific interaction with the T-rich strand of the ARS core consensus. Although these proteins do not appear to be functionally equivalent to replication initiators such as simian virus $40 \mathrm{~T}$ antigen, it has been speculated that they may participate in an unwound origin-protein complex. Several other DNAbinding proteins with undefined sequence specificity have been shown to interact with regions immediately flanking the core consensus sequence also required for optimal ARS activity $(24,72)$. One of these proteins, DBF-A, copurifies with an ATP-dependent helicase activity, further suggesting a role in DNA replication (72).

Several laboratories have independently identified an abundant DNA-binding protein that interacts with the sequence motif RTCRYN ${ }_{5}$ ACG in either the $3^{\prime}$ or $5^{\prime}$ flanking region of domain $A$ in a subset of ARS elements $(8,24,29$, $30,31,62,68)$. Site-directed mutagenesis of the ABF1 binding site at $A R S 121$ resulted in a large decrease in the stability of plasmids bearing this ARS (74), while deletions of this site at $A R S 1(24,67,69)$ and the HMRE ARS (4) had a smaller but detectable effect on $A R S$ plasmid stability. In 
addition, Walker et al. (73) showed that the ABF1 binding site enhances the activity of $A R S 121$ in an orientationindependent manner and at distances up to $1.2 \mathrm{~kb}$ from the ARS core consensus. These findings suggest that ABF1 plays an auxiliary role in the initiation of DNA replication similar to that of the mammalian transcription and viral replication proteins NFI/CTF (44) and NFIII/OCT-1 (55). In addition to their locations at ARSs, ABF1 binding sites are found at regions involved in transcription control, including the silencer elements of the nontranscribed mating-type loci $H M R$ and $H M L(8,24,62,68)$ and the promoters of as many as 80 genes $(9,21,22,27,35,36,59)$. At $H M R E$, the ABF1 binding site in combination with either an ARS consensus sequence or the binding site for the transcription repressor/ activator protein RAP1 is required for the transcriptional repression of the adjacent $H M R$ locus $(4,47)$. In the promoters for a variety of genes, the ABF1 binding site acts as an upstream activating sequence (UAS) involved in constitutive or carbon source-regulated transcriptional activation, depending on its context $(6,9,16,21,22,27,28,34-36,38,64)$. In fact, the $\mathrm{ABF} 1$ binding site from the $H M R E$ silencer can act as a UAS element in the context of a heterologous promoter $(4,9)$. As many as a dozen laboratories have independently identified DNA-binding proteins (TAF, GF1, SUF, and BAP1) that interact with these transcriptional elements $(6,16,21,22,27,35,36,38)$. Most of these proteins have been shown to be immunologically or genetically identical to $\operatorname{ABF} 1(6,16,28,34,64)$. However, the possibility also exists that a DNA-binding protein different from ABF1 interacts at these sites (2).

The fact that the $A B F 1$ gene is essential for cell viability $(25,34,59)$ and that overproduction of $A B F 1(58)$ results in arrested growth verifies the importance of this protein in yeast growth. To better understand the roles of ABF1 in DNA replication and transcription and to verify that a single protein is responsible for the diverse effects of the cis-acting sites, we have isolated conditionally lethal mutations in the $A B F 1$ gene. The requirements for ABF1 in ARS activity, cell cycle progression, and transcriptional activation were examined in strains containing these mutations. The results of these experiments provide evidence that the same protein, $A B F 1$, plays a fundamental role both in the initiation of DNA replication at ARSs and in transcriptional control in yeast cells.

\section{MATERIALS AND METHODS}

Plasmids, strains, and growth media. Plasmid stability assays were performed on the $A R S 1-C E N 4$ plasmid YCpG1 (67), the $A R S 121-C E N 3$ plasmid YCp5AB121 (74), and the $H 4 A R S-C E N 3$ plasmid $\mathrm{YCp} 5 \mathrm{H} 4$, generated by replacing the EcoRI-HindIII ARS121 fragment of YCp5AB121 with the EcoRI-HindIII H4 ARS fragments of pAB9 (3). An ARSI$C E N 3$ plasmid, YCp5A1, was also constructed by replacing the EcoRI-HindIII ARS121 fragment of YCp5AB121 with the EcoRI-HindIII ARSI fragment of YRp17. This plasmid gave the same loss rates as did YCpG1. The CYCl-lacZ reporter gene plasmid pLG $\triangle \mathrm{B}$ and the $4 X A R E-C Y C 1-l a c Z$ construct were described by Harshman et al. (37). The $A B S-C Y C 1-$ lac $Z$ construct was made by inserting the double-stranded oligonucleotide

\section{GATCCATTTCGTCAAAAATGCTAAGAAATCTGCA GTAAAGCAGTTTTTACGATTCTTTAG}

containing the ABF1 binding site from $A R S 1$ into BamHIPstI-digested pBluescript $\mathrm{SK}^{-}$(Stratagene) and then sub- cloning the BamHI-SalI fragment into pLG $\Delta \mathrm{B}$ linearized with BglII and Sall. Plasmid YEp24-4c was isolated from a yeast genomic library in YEp24 as described previously (59) and contains a 9-kb insert that includes the $A B F 1$ gene. Plasmid pR1190 was constructed by replacing the 3.4-kb BamHI-NdeI fragment containing the URA3 gene in YCp19 with the 5.3-kb BamHI-NdeI fragment containing the $A B F 1$ gene from YEp24-4c. For the structure-function studies shown in Fig. 8, a series of $3^{\prime}$ deletions in the $A B F 1$ gene, $\mathrm{H} 2.6$ to $\mathrm{H} 0.7$, was generated by restriction digestions and exonuclease III digestions. $\mathrm{H} 2.6$ contains the entire coding region of $A B F 1$. $\mathrm{H} 1.1$ and $\mathrm{H} 2.1$ extend to the first and second $\mathrm{BalI}$ sites in the coding region, respectively (nucleotides 1118 and 2090) (59). H1.6 extends to nucleotide 1613 , and $\mathrm{H} 0.7$ extends to nucleotide 695 . Transcriptional termination signals, included in a 1-kb fragment originating 40 bases upstream of the first translation termination codon, were subcloned $3^{\prime}$ to each of these deletions. Stop codons appear in every reading frame within the first 130 bases of the termination signals. These constructs, which carry the $A B F I$ promoter (HindIII to the initiation codon), were subcloned into the shuttle vector pRS316 (CEN6, H4 ARS, URA3) (63).

Escherichia coli TG1 cells were used for routine cloning procedures. The yeast strains used in this study are described in Table 1 . Strain JCA11 was constructed by transforming the JCA10 diploid with YEp24-4c, sporulating, and selecting for $\mathrm{URA}^{+} \mathrm{LEU}^{+}$haploid segregants. This strain was not viable on 5-fluoroorotic acid media as a result of the loss of the plasmid-borne $A B F I$ gene. The $a b f l(T s)$ alleles (abfl-1, abf1-2, and $a b f 1-5)$ were integrated into the chromosome as follows: the 1.8-kb BamHI fragment containing the $H I S 3$ gene was subcloned into the $B g$ lII site $5^{\prime}$ to the $a b f l$ (Ts) genes (or $A B F l$ gene). Previously we had shown that this region was not essential for cell viability. DNA fragments carrying the $a b f l(\mathrm{Ts})$ or $A B F 1$ genes linked to HIS3 were used to transform YNN281 and YNN282 to HIS ${ }^{+}$ phototrophy. Replacement of the chromosomal $A B F 1$ gene was verified by Southern analysis. Transformants were also tested for complementation of temperature-sensitive growth by the YEp24-4c $\left(A B F 1^{+}\right)$plasmid. Other strategies for integrating the mutant alleles proved unsuccessful. JCA55 was a haploid segregant from a cross between AJ116 barl-1 and JCA45 abfl-1 that showed both temperature-sensitive growth (complemented by YEp24-4c) and sensitivity (shmoo formation and growth arrest) to $0.3 \mu \mathrm{g}$ of $\alpha$-factor per ml. Strain JCA 50 was constructed by replacing the $a b f 1-5$ allele of JCA55 with the wild-type $A B F I$ gene by one-step gene replacement.

Strains carrying the temperature-sensitive lethal mutations were grown at 23 to $25^{\circ} \mathrm{C}$ as the permissive temperature, $30^{\circ} \mathrm{C}$ as the semipermissive temperature, and 37 to $38^{\circ} \mathrm{C}$ as the nonpermissive temperature. All media were prepared as described previously (59). Yeast DNA transformations were carried out by the lithium acetate method of Ito et al. (42).

Generation of abf1(Ts) alleles. The plasmid shuffling strategy described by Budd and Campbell (11) was used to isolate abfl(Ts) alleles. Briefly, the ABFI gene on the TRPI-ARSICEN4 plasmid pR1190 was randomly mutagenized in vitro by incubation with hydroxylamine for either 3 or $4 \mathrm{~h}$ according to the procedure of Busby et al. (13). The plasmids treated for $3 \mathrm{~h}$ transformed $E$. coli cells at $5 \%$ the efficiency of unmutagenized pR1190, while the transformation efficiency of the 4-h sample was $0.7 \%$. Samples of both mutagenized populations were used to transform JCA11, a yeast 
TABLE 1. Strains

\begin{tabular}{|c|c|c|}
\hline Strain & Genotype & Reference or source \\
\hline JCA10 & 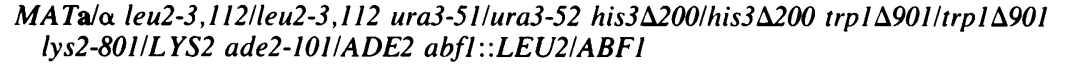 & 59 \\
\hline JCA11 & 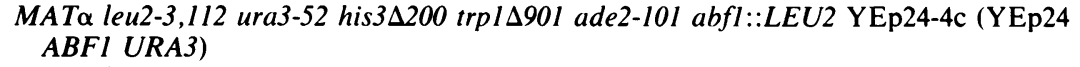 & \\
\hline JCA20 & 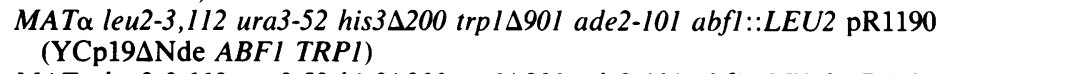 & \\
\hline JCA21 & 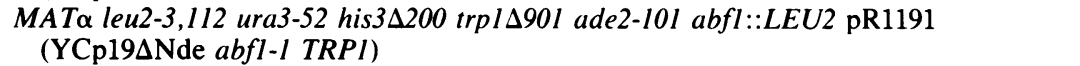 & \\
\hline JCA23 & 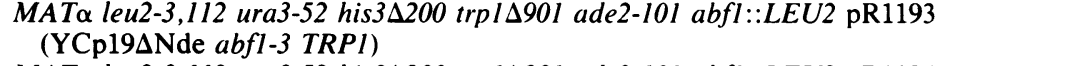 & \\
\hline JCA24 & 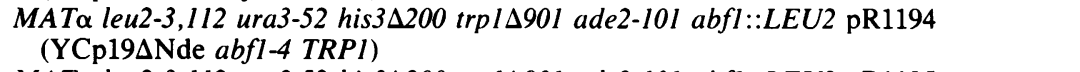 & \\
\hline JCA25 & 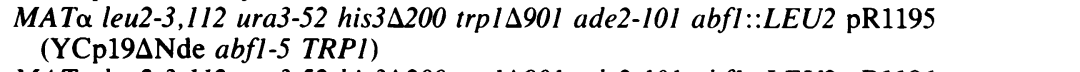 & \\
\hline JCA30 & 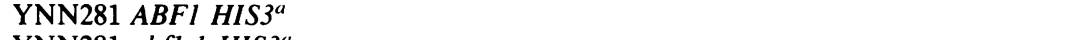 & \\
\hline JCA31 & YNN281 abfl-1 HIS3 ${ }^{a}$ & \\
\hline JCA32 & YNN281 abfl-2 HIS3 ${ }^{a}$ & \\
\hline JCA35 & YNN281 $a b f 1-5 H_{I S 3^{a}}$ & \\
\hline $\begin{array}{l}\text { JCA40 } \\
\text { JCA41 }\end{array}$ & $\begin{array}{l}\text { YNN282 } A B F I \quad H I S 3^{a} \\
\text { YNN282 } a b f 1-1 \text { HIS3 }\end{array}$ & \\
\hline JCA42 & YNN282 abfl-2 HIS3 ${ }^{a}$ & \\
\hline JCA45 & YNN282 abfl-5 HIS3 ${ }^{a}$ & \\
\hline AJ116 & MATa barl-1 leul met trp5 ura3 canl & $\begin{array}{l}\text { A. Jong, University of Southern } \\
\text { California }\end{array}$ \\
\hline $\begin{array}{l}\text { JCA50 } \\
\text { JCA55 }\end{array}$ & $\begin{array}{l}\text { MATa barl-1 ura3 lys2-801 met ABFI HIS3 } \\
\text { MATa barl-1 ura3 lys2-801 met abfl-5 HIS3 }\end{array}$ & \\
\hline
\end{tabular}

a The $A B F I H I S 3$ notation indicates that $H I S 3$ was integrated at the $A B F I$ locus along with each $a b f l$ allele.

strain carrying a chromosomal disruption of the $a b f l$ gene and a wild-type $A B F I$ gene on a $U R A 3$ plasmid. Transformants carrying both plasmids were picked and screened for growth at 23 and $37^{\circ} \mathrm{C}$ to eliminate cells with temperaturesensitive mutations that are not recessive to the wild-type $A B F 1$ gene (i.e., unlinked or dominant lethal $A B F l$ mutants). Transformants were also screened for growth at 23 and $37^{\circ} \mathrm{C}$ on plates containing 5-fluoroorotic acid to counterselect against the URA3-ABFI YEp24-4c plasmid. Of the 3,000 independent transformants picked, 9 gave temperature-sensitive growth and 49 (null mutations) failed to grow at 23 or $37^{\circ} \mathrm{C}$ on 5 -fluoroorotic acid plates. When rescued from the temperature-sensitive strains into $E$. coli and retested by the plasmid shuffling protocol, six plasmids gave temperaturesensitive growth that was recessive to the wild-type $A B F I$ gene. Three of the $a b f l(\mathrm{Ts})$ alleles were used to replace the chromosomal copy of the $A B F I$ gene in a one-step gene replacement strategy described above.

To map the locations of the mutations responsible for the temperature-sensitive phenotype, we carried out marker rescue experiments as described by Budd et al. (12). Plasmids pMR1, pMR2, and pMR3 carrying different regions of the $A B F I$ gene were constructed in the $2 \mu \mathrm{m} A R S-U R A 3$ vector pSEY18. pMR1 contains the $A B F I 5^{\prime}$ flanking and coding region (1.1-kb HindIII-StuI fragment), pMR2 contains the middle of the coding region (0.9-kb StuI-KpnI fragment), and pMR3 contains the $3^{\prime}$ coding and flanking region (1.25-kb KpnI-SpeI fragment). Upon transformation into the $a b f l(\mathrm{Ts})$ strains, these plasmids were tested for the ability to rescue temperature-sensitive growth at $37^{\circ} \mathrm{C}$ via random recombination or gene conversion events. Once the region of the gene containing the $a b f l(T s)$ mutation was defined, it was sequenced by the dideoxynucleotide method on double-stranded DNA with oligonucleotide primers specific to the $A B F l$ gene.

Cell synchrony. A MATa abfl-5 barl strain, JCA55, was constructed as described above and used to improve cell cycle arrest following treatment with $\alpha$-factor. Cultures grown to early log phase $\left(A_{600}=0.3\right)$ at $25^{\circ} \mathrm{C}$ in YPD were treated with $\alpha$-factor $(0.3 \mu \mathrm{g} / \mathrm{ml})$ for $6 \mathrm{~h}$. By this time, 80 to $90 \%$ of the cells were unbudded. The growth medium was removed by filtration, and the cells were washed extensively with medium. The cells were resuspended in fresh medium to an $A_{600}$ of 0.5 and incubated at 23 or $37^{\circ} \mathrm{C}$. For incorporation time courses, cells were resuspended in synthetic medium, whereas cells analyzed by flow cytometry were resuspended in YPD. In reciprocal shift experiments, $a b f 1-5$ cultures were incubated at the nonpermissive temperature and then treated with $\alpha$-factor at the permissive temperature. These cells failed to progress synchronously through the cell cycle because of multiple cell cycle arrest points and slow recovery of the $a b f l-5$ mutant.

Macromolecular synthesis. In vivo levels of DNA and RNA synthesis were determined as described by Budd and Campbell (11), with slight modifications. Cells grown at $23^{\circ} \mathrm{C}$ in YPD were harvested in early log phase $\left(A_{600}=0.5\right)$ and resuspended in synthetic medium containing $7 \mu \mathrm{Ci}$ of $\left[{ }^{3} \mathrm{H}\right]$ uracil per $\mathrm{ml}$. The culture was split and incubated at 23 or $37^{\circ} \mathrm{C}$ for various times. For RNA synthesis determination, $0.1-\mathrm{ml}$ aliquots were removed and precipitated with $10 \%$ 
trichloroacetic acid (TCA)-0.1 M sodium pyrophosphate. The 0.4-ml aliquots taken for DNA synthesis determination were treated with $\mathrm{NaOH}$ to a final concentration of $1 \mathrm{M}$ at $37^{\circ} \mathrm{C}$ for $24 \mathrm{~h}$. The samples were neutralized to $\mathrm{pH} 7$ with 0.1 $\mathrm{M}$ Tris $\cdot \mathrm{HCl}$, digested for $2 \mathrm{~h}$ at $37^{\circ} \mathrm{C}$ with $0.5 \mu \mathrm{g}$ of RNase A per $\mathrm{ml}$, and precipitated with $10 \%$ TCA-0.1 M sodium pyrophosphate. Protein synthesis rates were measured in 0.5 -ml samples incubated with $10 \mu \mathrm{Ci}$ of Trans ${ }^{35} \mathrm{~S}$ (ICN). The samples were precipitated with $10 \%$ TCA. All the samples were assayed in duplicate or triplicate, and each experiment was repeated at least three times.

DNA binding analysis. Yeast strains carrying the plasmidborne $a b f l(\mathrm{Ts})$ alleles $(100 \mathrm{ml})$ were grown to early log phase at $23^{\circ} \mathrm{C}$, split, and incubated at 23 or $37^{\circ} \mathrm{C}$ for $3 \mathrm{~h}$. The cells were harvested and yeast extracts were prepared as described previously (59). ABF1-DNA binding activity was measured by incubation with $20 \mu \mathrm{g}$ of protein and $2 \mathrm{ng}$ of ${ }^{32}$ P-labeled HindIII-BglII fragment from YRp7 (ARSI domain $B$ ) in the presence of $3 \mu \mathrm{g}$ of salmon sperm DNA as a nonspecific competitor for $15 \mathrm{~min}$ at $4^{\circ} \mathrm{C}$. Gel retardation analysis was carried out at $25^{\circ} \mathrm{C}$ as described by Sweder et al. (68). To test in vitro DNA binding at the nonpermissive temperature, the binding reaction $(10 \mathrm{~min})$ and gel retardation were performed at $37^{\circ} \mathrm{C}$. Western immunoblot analysis on $50 \mu \mathrm{g}$ of the cell extract was carried out as described previously, using anti-ABF1 monoclonal antibody $6 \mathrm{C} 11 \mathrm{G} 4$.

Mitotic plasmid stability assay. Single transformants were picked, grown under selective conditions overnight, diluted into nonselective YPD, and grown for 6 to 12 generations at 23 or $30^{\circ} \mathrm{C}$. Aliquots of the initial and final culture were diluted, plated on YPD plates, and grown at $25^{\circ} \mathrm{C}$. When colonies appeared, they were counted and replica spotted onto selective medium (medium minus uracil). The plasmid loss rate per generation was determined by $1-(F / n)^{1 / N}$, where $I$ is the initial percentage of plasmid-containing cells and $F$ is the percentage of plasmid-containing cells after $N$ generations of growth in nonselective medium. Plasmid loss determinations were made on at least four independent transformants for each plasmid.

$\beta$-Galactosidase assays. Yeast extracts prepared from $5 \mathrm{ml}$ of early-log-phase cultures were assayed for $\beta$-galactosidase as described by Harshman et al. (37). Protein concentrations were determined by the Bradford assay. Specific activity of $\beta$-galactosidase was expressed as picomoles of $o$-nitrophenol produced per minute per milligram of protein. Measurements were made on at least four independent transformants per plasmid.

Flow cytometry. Samples collected for cell cycle analysis were fixed with $70 \%$ ethanol overnight at $4^{\circ} \mathrm{C}$. The cells were pelleted and washed with $0.2 \mathrm{ml}$ of Tris-buffered saline (50 $\mathrm{mM}$ Tris $\cdot \mathrm{HCl}$ [pH 7.5], $150 \mathrm{mM} \mathrm{NaCl}$ ). Following digestion in $0.5 \mathrm{mg}$ of RNase A per $\mathrm{ml}$ for $2 \mathrm{~h}$ at $37^{\circ} \mathrm{C}$, the cells were pelleted and resuspended in $0.3 \mathrm{ml}$ of $100-\mu \mathrm{g} / \mathrm{ml}$ propidium iodide. The cells were briefly sonicated to break up aggregates, diluted to $10^{6}$ cells per ml in Tris-buffered saline, and analyzed on an Ortho Cytofluorograf 50H-2150.

\section{RESULTS}

Isolation and characterization of $a b f 1$ (Ts) mutants. A plasmid shuffling strategy was used to obtain temperaturesensitive mutations in the $A B F I$ gene by introducing mutagenized copies of a plasmid-borne $A B F 1$ gene into JCA11 cells carrying a disruption in the essential chromosomal copy. Of the 3,000 colonies screened, nine mutants were identified that confer temperature-sensitive growth. By re-

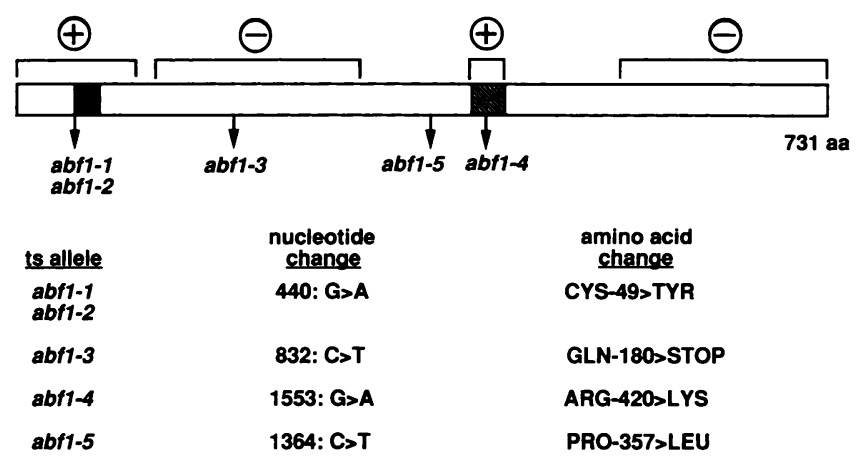

FIG. 1. Allele map of $a b f 1$ (Ts) mutants. The bar represents the open reading frame of the $A B F I$ gene and the relative positions of the $a b f 1$ (Ts) mutations. The solid block represents the putative metal binding motif; the striped block represents the basic region. At the top are the relative regions of charge distribution across this highly acidic (net charge at $\mathrm{pH} 7=-60$ ) protein. The nucleotide and corresponding amino acid (aa) changes are shown. The positions of the nucleotides and amino acids are based on sequence analysis described in Rhode et al. (59).

peating the plasmid shuffling technique on plasmids recovered from these mutants, we found that six mutations were plasmid linked and recessive to the wild-type $A B F I$ gene. Marker rescue experiments were carried out to define the regions of the $A B F I$ gene responsible for the temperaturesensitive phenotype. DNA sequence analysis identified single-point mutations for five of the abfl(Ts) alleles (Fig. 1). In each case, the mutations were C-to-T transitions, as expected for hydroxylamine mutagenesis.

The five mutations mapped to date fall within the N-terminal two-thirds of the protein. This region has been shown to be required for DNA binding activity (34; see below). Two of the mutations (abfl-l and $a b f l-2$ ) were identical changes at nucleotide 440 resulting in a change of cysteine at position 49 to tyrosine. This residue falls within a region of the protein, C-49- $\mathrm{X}_{7}-\mathrm{H}-57-\mathrm{X}_{3}-\mathrm{H}-61-\mathrm{X}_{4}-\mathrm{C}-66-\mathrm{X}_{4}-\mathrm{C}-71$, that loosely resembles a metal binding motif $(25,34,59)$. Previous mutational analysis showed that substitutions at $\mathrm{H}-57$ or C-71 resulted in a mutant protein that, when isolated from $E$. coli, could no longer specifically bind DNA with high affinity (34). The mutation at nucleotide 1553 in the abfl -4 allele falls in a basic region of the protein. This mutation results in a conservative arginine-to-lysine substitution at position $\mathbf{4 2 0}$. The mutation producing the temperature-sensitive phenotype of the abfl-3 allele gives rise to a termination codon at position 180 . We believe that this termination codon is suppressed in this strain, since extracts from this mutant still contain full-length ABF1 protein, as inferred from Western analysis (data not shown) and gel retardation analysis (see Fig. 3). The fifth mutation, $a b f l-5$, is a proline-to-leucine change at amino acid 357 and therefore likely affects the structure of ABF1 rather than a specific active site, such as a DNA binding site.

Because of the high reversion rate of the sixth allele, $a b f 1-6$, marker rescue experiments proved inconclusive. However, sequence analysis of this allele failed to reveal any changes in the coding sequence.

DNA binding in abf1(Ts) mutants. Since five of the temperature-sensitive mutations mapped to a broad region of ABF1 important for DNA binding, we were interested in whether DNA binding was affected in the mutant proteins. Cell extracts were prepared from the abfl(Ts) mutants 
A)

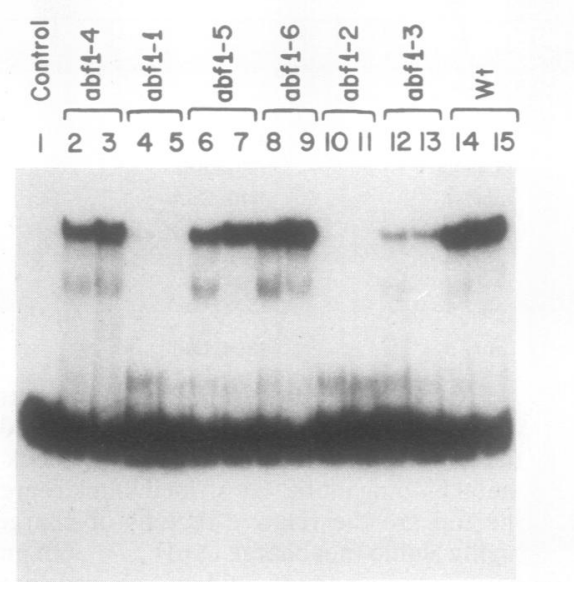

B)

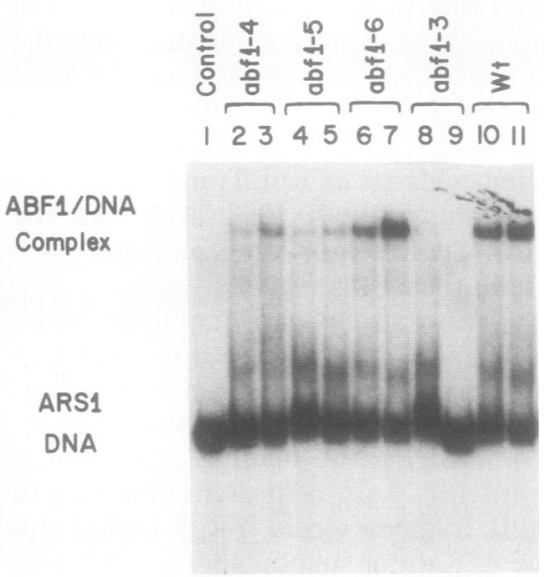

FIG. 2. DNA binding activities of $a b f l(T s)$ proteins. Extracts from $a b f l(T s)$ strains were prepared as described previously (59). Gel retardation analysis was used to detect ABF1 binding activity to a labeled DNA fragment containing the ABF1 binding site on domain B of $A R S 1$ as described in Materials and Methods. (A) Standard assay conditions (binding at $0^{\circ} \mathrm{C}$ for 15 min, gel run at $25^{\circ} \mathrm{C}$ ) were used. Lane 1 contains no protein; lanes $2,4,6,8,10,12$, and 14 contain $20 \mu \mathrm{g}$ of protein from cells grown at $23^{\circ} \mathrm{C}$; lanes $3,5,7,9,11,13$, and 15 contain $20 \mu \mathrm{g}$ of protein from cells shifted to $37^{\circ} \mathrm{C}$ for $4 \mathrm{~h}$. Positions of the free $A R S I$ DNA probe and ABF1-DNA complexes are indicated. (B) Gel retardation assays were carried out at the nonpermissive temperature (binding at $37^{\circ} \mathrm{C}$ for $10 \mathrm{~min}$, gel run at $37^{\circ} \mathrm{C}$ ) on the samples that showed ABF1 binding activity under standard conditions. Lane 1 contains no protein; lanes $2,4,6,8$, and 10 contain $20 \mu \mathrm{g}$ of protein from cells grown at $23^{\circ} \mathrm{C}$; lanes $3,5,7,9$, and 11 contain $20 \mu \mathrm{g}$ of protein from cells shifted to $37^{\circ} \mathrm{C}$ for $4 \mathrm{~h}$. Wt, wild type.

maintained at permissive and nonpermissive temperatures and were used in gel retardation assays with an ARSI DNA probe. When standard assay conditions were used, ABF1DNA binding complexes were observed in extracts from $a b f 1-3, a b f 1-4, a b f 1-5$, and $a b f l-6$ strains, but little or no ABF1 binding activity was observed in the $a b f l-1$ (or $a b f l-2$ ) extracts (Fig. 2A). A protein-DNA complex of higher mobility than the ABF1-DNA complexes was observed in extracts from $a b f 1-1$ strains. However, competitive binding studies indicated that the faster-migrating complexes were not specific to the ABF1 binding site (59). The absence of any binding species in the $a b f l-1,2$ mutant makes it unlikely that there are other abundant ABF1-like binding activities present in these extracts. The absence of $\mathrm{ABF} 1$ binding activity in the $a b f 1-1$ strain was not due to reduced protein levels. Western analysis indicated that wild-type levels of the ABF1 protein doublet were observed in each of the mutants except the $a b f l-3$ strain, which had about $20 \%$ of wild-type levels of ABF1 (data not shown). For each mutant, only slight differences were seen between the level of binding activity in extracts from cells maintained at either the permissive or nonpermissive temperature, suggesting that there is not rapid decay of the protein at high temperatures.

To determine whether any of the mutant proteins showed thermolabile binding, we performed gel retardation assays at $37^{\circ} \mathrm{C}$ (Fig. 2B). Under these assay conditions, ABF1 binding activity in extracts of the $a b f l-3, a b f 1-4$, and $a b f l-5$ mutants was lower than that seen in extracts from the wild-type strain or in comparison with binding at $23^{\circ} \mathrm{C}$ (Fig. 2A), indicating thermolability of the mutant proteins. The lack of $A B F 1$ binding activity in the $a b f l-1$ strain at all temperatures and the thermolability of this activity in the $a b f l-3, a b f 1-4$, and $a b f 1-5$ strains suggest that the mutations fall at residues that interact with the DNA or are important for the structural integrity of the DNA binding domain. The fact that reduced ABF1 binding activity was observed in vitro at the nonper- missive temperature for the $a b f l-3$ allele suggests that suppression of the nonsense mutation results in a thermolabile protein. The abfl-6 mutant showed wild-type levels of ABF1 binding activity with no apparent temperature sensitivity, again consistent with the deduced location of the abfl-6 lesion outside of the DNA binding domain.

Properties of abfl(Ts) mutants. To examine growth arrest of the $a b f l(\mathrm{Ts})$ mutants, we plated JCA11 cells carrying the various plasmid-borne $a b f l(T s)$ alleles on solid media and incubated the cells at the nonpermissive temperature for 2 days. Three of the mutants ( $a b f l-1, a b f 1-2$, and $a b f 1-5$ ) showed little or no growth at $37^{\circ} \mathrm{C}$, while the other mutants (abfl-3, $a b f 1-4$, and $a b f 1-6)$ grew slowly, forming small colonies. The $a b f l(T s)$ alleles that gave rapid growth arrest were used to replace the chromosomal copy of the $A B F I$ gene as described in Materials and Methods. Growth of these mutants arrested in a single cell cycle at the nonpermissive temperature, as determined microscopically. As shown in Fig. 3, the arrested cells were enlarged and had small elongated buds (see legend to Fig. 3). Some buds contained DNA (not shown), and some did not. This phenotype is distinct from that of any known cell division cycle mutants that arrest at $G_{1} / S$, though it resembles that of cells overproducing STE12p, a transcription factor involved in pheromone-responsive gene expression (26). The complex appearance may be due to arrest at two points in the cycle (see also Fig. 5). The growth rate of the $a b f 1-1$ mutants at the permissive temperature is nearly identical to that of the isogenic ABF1 strain, while the $a b f l-5$ strains grew more slowly. Both $a b f l-1$ and $a b f l-5$ strains grew slowly at $30^{\circ} \mathrm{C}$ but arrested growth at temperatures of $\geq 32^{\circ} \mathrm{C}$.

ARS activity is reduced in abf1(Ts) strains. Mutational analysis of the ABF1 binding sites in $A R S 1, A R S 121$, and the $H M R E$ ARS suggest that ABF1 plays an important role in ARS function. To determine directly the requirements of different ARSs for ABF1 function, we measured the ARS activity for three $A R S-C E N$ plasmids (ARS1, ARS121, and 

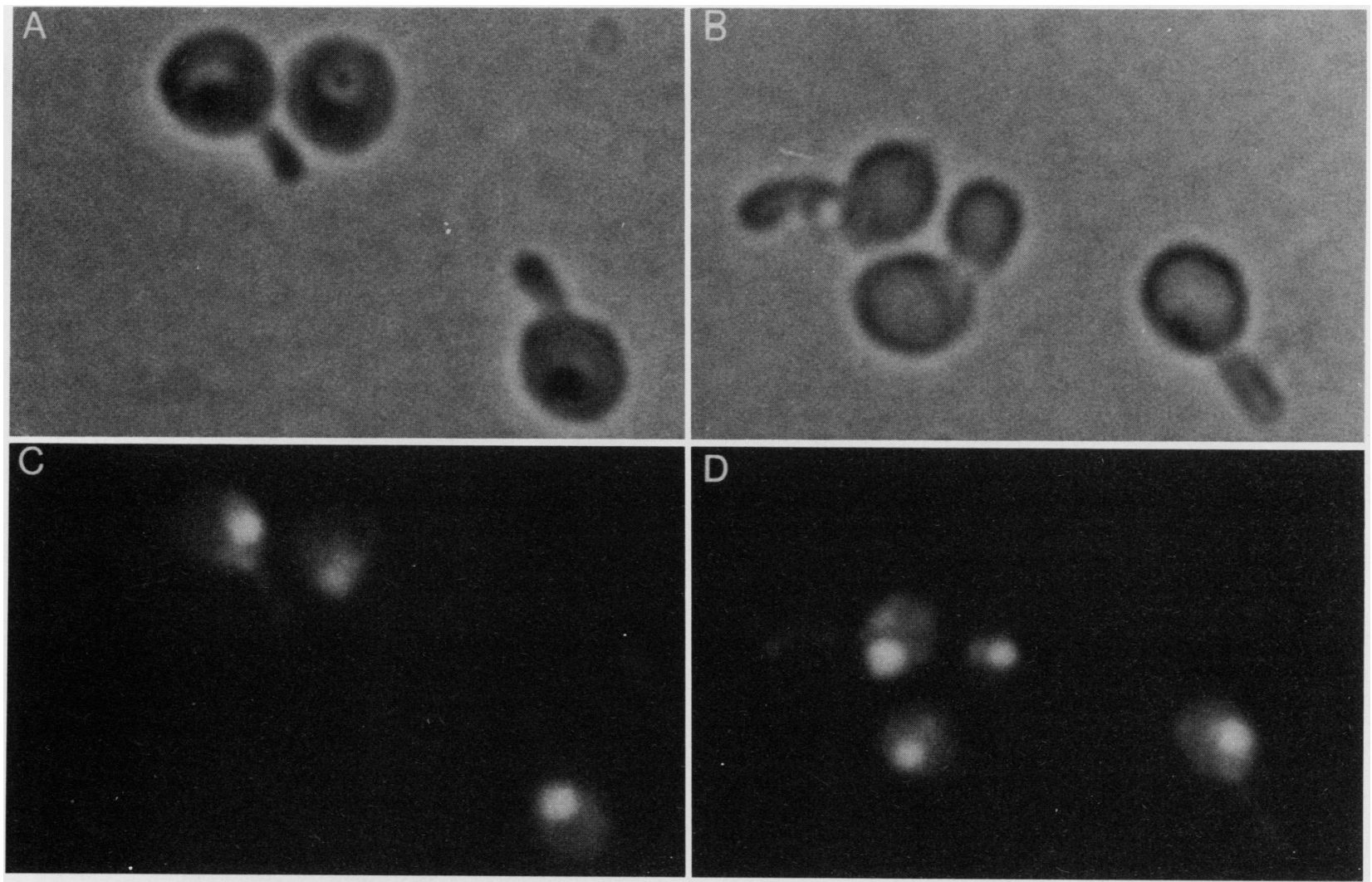

FIG. 3. Arrest phenotypes of $a b f 1-1$ mutants. JCA41 ( $a b f 1-1)\left(\right.$ A and C) and JCA45 $(a b f 1-5)$ (B and D) strains were grown at $23^{\circ} \mathrm{C}$ to early $\log$ phase and then shifted to $37^{\circ} \mathrm{C}$ for $4 \mathrm{~h}$. The cells were harvested and fixed with methanol-acetic acid (3:1), and the nuclei were stained with 4',6-diamidino-2-phenylindole as described previously (43). (A and B) Phase-contrast field; (C and D) fluorescence field. Percentages of cells with elongated buds: $a b f 1-1,70 \% ; a b f 1-5,40 \% ; A B F 1,0 \%$.

H4 ARS) in abfl(Ts) strains maintained at permissive and semipermissive growth temperatures. Of the ARSs tested, $A R S 121$ and $A R S 1$ have well-characterized high-affinity ABF1 binding sites, such that purified ABF1 has a fivefoldhigher affinity for $A R S 121$ than for $A R S 1$ (30). ABF1 fails to recognize the $H 4$ ARS with high affinity (8). Previous studies have also shown that $A R S I 21$ has two ABF1 binding sites within domain $B$, which when deleted result in an increase in plasmid instability (as measured by plasmid loss per gener- ation in nonselective conditions) from about $5 \%$ for the wild-type ARS121 to about $12 \%$ for the domain B-deletion mutant $(73,74)$. Similarly, deletions into the single ABF1 binding site in domain $\mathrm{B}$ of $A R S 1$ result in an increase in plasmid loss rate from $10 \%$ for the wild-type ARS1 to $13 \%$ for the domain B-deletion mutant (24).

When the mitotic stability of these ARS plasmids was examined in the $a b f l$ (Ts) strains grown at the semipermissive temperature, $A R S 121$ and the H4 ARS plasmids showed

TABLE 2. ARS plasmid stability in $a b f l(T s)$ strains

\begin{tabular}{|c|c|c|c|c|c|c|c|c|c|}
\hline \multirow{2}{*}{$\begin{array}{c}\text { ARS } \\
\text { plasmid }\end{array}$} & \multirow{2}{*}{ Strain } & \multicolumn{4}{|c|}{ Semipermissive temp $\left(30^{\circ} \mathrm{C}\right)$} & \multicolumn{4}{|c|}{ Permissive temp $\left(25^{\circ} \mathrm{C}\right)$} \\
\hline & & Selective & Nonselective & $\begin{array}{c}\% \text { Plasmid } \\
\text { loss/generation }\end{array}$ & Ratio $^{b}$ & Selective & Nonselective & $\begin{array}{c}\% \text { Plasmid } \\
\text { loss/generation }\end{array}$ & Ratic \\
\hline \multirow{2}{*}{ ARS121 } & $a b f 1-5$ & $68.8 \pm 5.2$ & $22.5 \pm 8.5$ & $13.2 \pm 3.7^{c}$ & 20 & $68.8 \pm 6.3$ & $45.0 \pm 6.5$ & $4.1 \pm 0.6$ & 1.3 \\
\hline & $A B F I$ & $76.9 \pm 4.0$ & $73.8 \pm 0.7$ & $0.7 \pm 0.3$ & & $80.0 \pm 3.5$ & $53.8 \pm 3.8$ & $3.1 \pm 0.5$ & \\
\hline ARSI & $a b f 1-1$ & $91.3 \pm 4.3$ & $72.5 \pm 6.0$ & $3.9 \pm 1.5$ & 1.5 & $92.5 \pm 3.2$ & $67.5 \pm 3.2$ & $2.5 \pm 0.4$ & 0.9 \\
\hline \multirow[t]{3}{*}{ H4 ARS } & $a b f 1-1$ & $88.8 \pm 4.3$ & $67.5 \pm 1.4$ & $4.3 \pm 0.4^{c}$ & 2.4 & $93.1 \pm 2.1$ & $78.8 \pm 5.5$ & $1.3 \pm 0.5$ & 0.6 \\
\hline & $a b f l-5$ & $85.0 \pm 6.5$ & $65.0 \pm 4.6$ & $3.6 \pm 0.6^{c}$ & 2.0 & $93.8 \pm 3.8$ & $75.0 \pm 4.1$ & $1.9 \pm 0.4$ & 1.0 \\
\hline & $A B F I$ & $93.8 \pm 2.4$ & $76.3 \pm 4.7$ & $1.8 \pm 0.5$ & & $93.8 \pm 1.3$ & $73.8 \pm 3.1$ & $2.0 \pm 0.3$ & \\
\hline
\end{tabular}

\footnotetext{
${ }^{a}$ Determined as $1-(F /)^{1 / N}$, where $I$ is the initial percentage of plasmid-containing cells and $F$ is the percentage of plasmid-containing cells after $N$ generations of growth in nonselective medium.

${ }^{b}$ Ratio of percent plasmid loss per generation of the $a b f l(T s)$ strain to that of wild-type strain.

${ }^{c}$ Percent plasmid loss per generation in the $a b f l(T s)$ mutant is significantly different $(P<0.02)$ from the loss rate in the wild-type strains.
} 

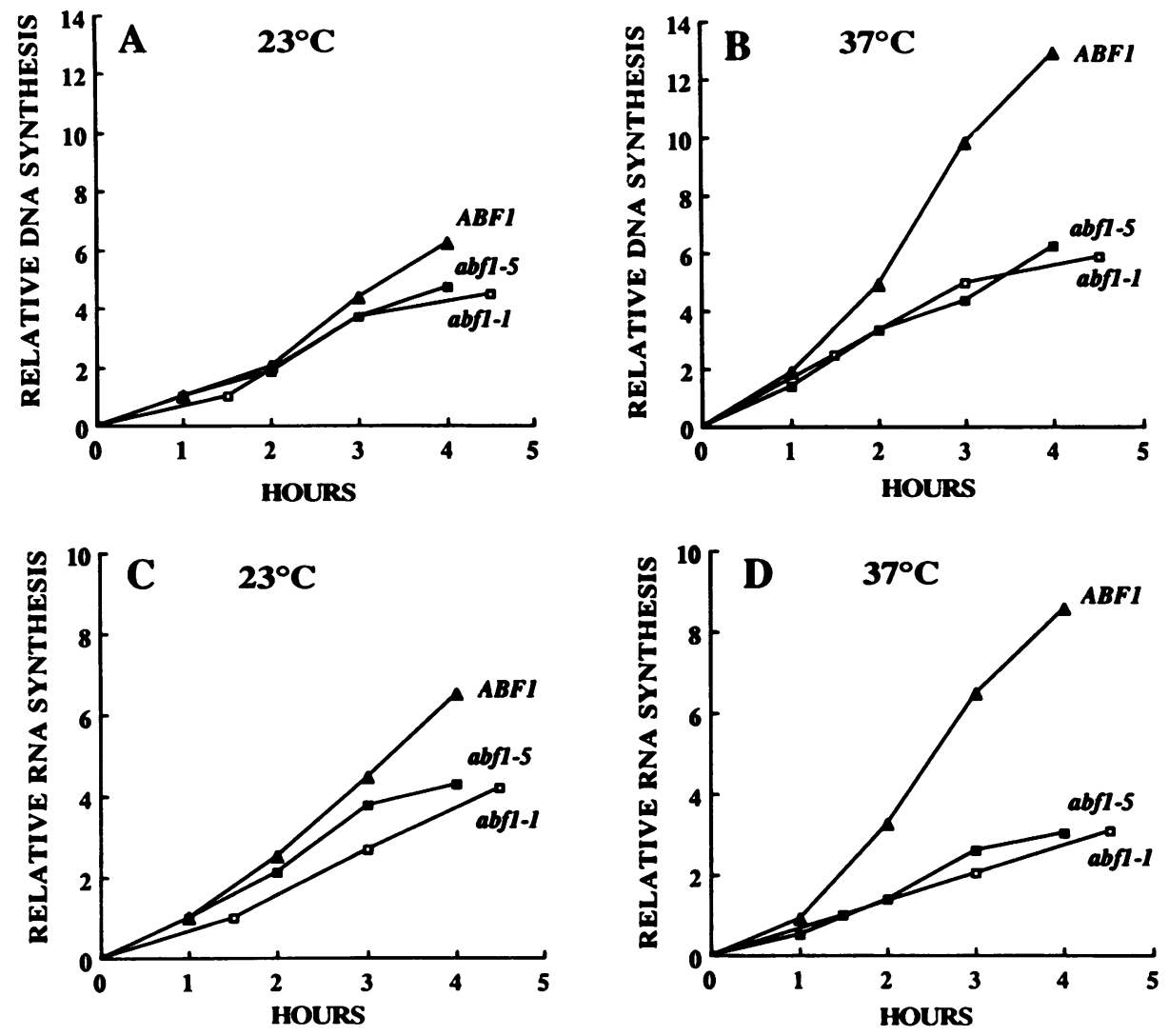

FIG. 4. DNA and RNA synthesis in abfl(Ts) mutant strains. $\left[{ }^{3} \mathrm{H}\right]$ uracil incorporation $(7 \mu \mathrm{Ci} / \mathrm{ml})$ into DNA and RNA was determined as described in Materials and Methods. To compare incorporation rates between strains, the level of incorporation (counts per minute per milliliter) for any given time was normalized to that seen after $1 \mathrm{~h}$ at $23^{\circ} \mathrm{C}$. The relative rates of DNA synthesis at $23^{\circ} \mathrm{C}(\mathrm{A})$ and $37^{\circ} \mathrm{C}(\mathrm{B})$ are shown for asynchronous JCA41 (abfl-1), JCA45 (abfl-5) and JCA40 (ABFl) strains. Similarly, relative RNA synthesis rates for these strains are shown for cultures grown at $23^{\circ} \mathrm{C}(\mathrm{C})$ and $37^{\circ} \mathrm{C}(\mathrm{D})$. Each point represents the average of duplicate determinations.

a statistically significant decrease in stability compared with loss rates measured in the wild-type strain (Table 2). Furthermore, differential effects were observed depending on the ARS element, indicating that this phenotype was not merely the result of a plasmid segregation defect or poor cell growth. In both $a b f 1-1$ and $a b f 1-5$ mutant strains, ARS121 plasmids were lost at a rate at least 20 -fold greater than that seen in wild-type cells. H4 ARS plasmids were lost at about 2-fold-greater rates in the $a b f l$ (Ts) mutants than in wild-type cells, while loss rates for $A R S 1$ plasmids were 1.5 - to 2.5-fold greater than wild-type rates in the two abfl(Ts) strains, respectively. This loss of stability was temperature dependent, since $a b f 1-1, a b f 1-5$, and wild-type strains showed little or no difference in plasmid loss rates at the permissive temperature (Table 2 ). These results provide evidence for a direct role for the $a b f l$ (Ts) protein in ARS activity. Furthermore, the magnitude of the effect of the $a b f l(\mathrm{Ts})$ alleles on $A R S 1$ and $A R S 121$ plasmid loss rates is comparable to the magnitude of the effect of ABF1 binding site mutations on ARS activity summarized above.

Efifects of the abf1(Ts) alleles on DNA and RNA synthesis in asynchronously growing cultures. The morphology of the $a b f 1$ (Ts) mutants arrested at $37^{\circ} \mathrm{C}$ (Fig. 3) gave no indication of a specific effect on cell cycle progression or DNA replication but suggested that ABF1 may be required at multiple points in the cell cycle. To examine the effect of ABF1 on cell growth in more detail, we measured DNA and RNA synthesis in the $a b f l$ (Ts) strains during incubation at the nonpermissive growth temperature. The strains were grown to early log phase at the permissive temperature, and the cultures were divided and incubated at permissive and nonpermissive temperatures in the presence of $\left[{ }^{3} \mathrm{H}\right]$ uracil. At various times, aliquots were removed and nucleotide incorporation into DNA and RNA was determined. At the permissive temperature, DNA and RNA synthesis rates were only slightly lower in the $a b f 1-1$ and $a b f 1-5$ cultures than in the wild-type culture (Fig. 4A and $\mathrm{C}$ ). In contrast, after $1 \mathrm{~h}$ at $37^{\circ} \mathrm{C}$, the extent of DNA synthesis in both $a b f 1-1$ and $a b f l-5$ strains was reduced to $50 \%$ of that seen in the wild-type strain and total RNA synthesis in these cultures was reduced to about $40 \%$ of wild-type levels (Fig. 4B and D). These findings are consistent with multiple roles for ABF1 documented from earlier studies involving mutagenesis of cis-acting DNA binding sites (see Discussion). The defect in RNA synthesis may represent a more general role of $\mathrm{ABF} 1$ in transcription than previously appreciated from the study of individual genes.

Although DNA synthesis at $37^{\circ} \mathrm{C}$ was lower in the $a b f 1$ (Ts) strains than in the wild type (Fig. 4B), it was not completely defective. In fact, DNA synthesis in the $a b f 1$ (Ts) strains continued for several hours at the same rate as was seen in cells grown at the permissive temperature, even though no division was observed for up to $6 \mathrm{~h}$ at the nonpermissive temperature. These results have two possible explanations. 


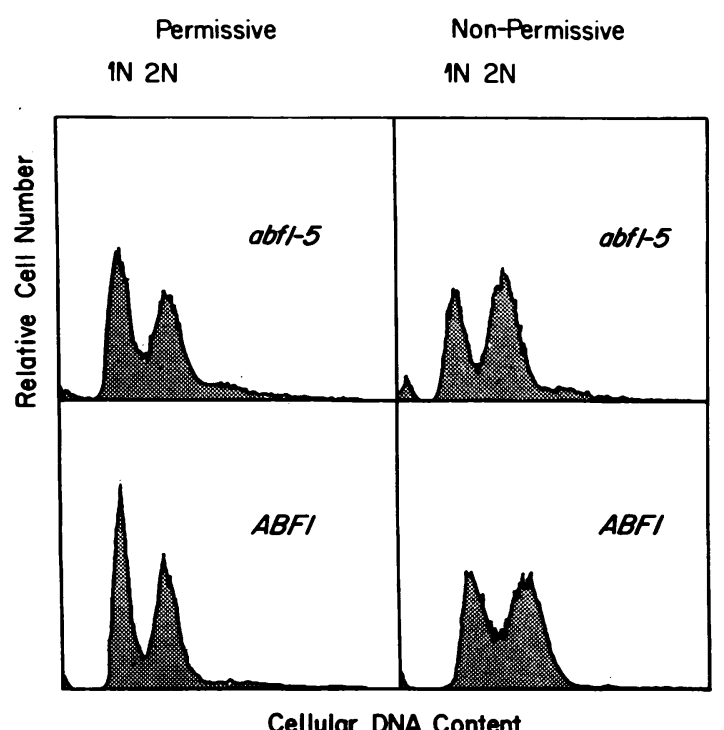

FIG. 5. Flow cytometric analysis of $a b f 1-5$ cells. JCA45 (abfl-5) cells were grown to early $\log$ phase at $23^{\circ} \mathrm{C}$ and shifted to $37^{\circ} \mathrm{C}$ for 4 $h$. The cells were then harvested and fixed with $70 \%$ ethanol, and cellular DNA was stained with propidium iodide as described in Materials and Methods. Shown are DNA histograms of the propidium iodide-stained cells determined by flow cytometry.
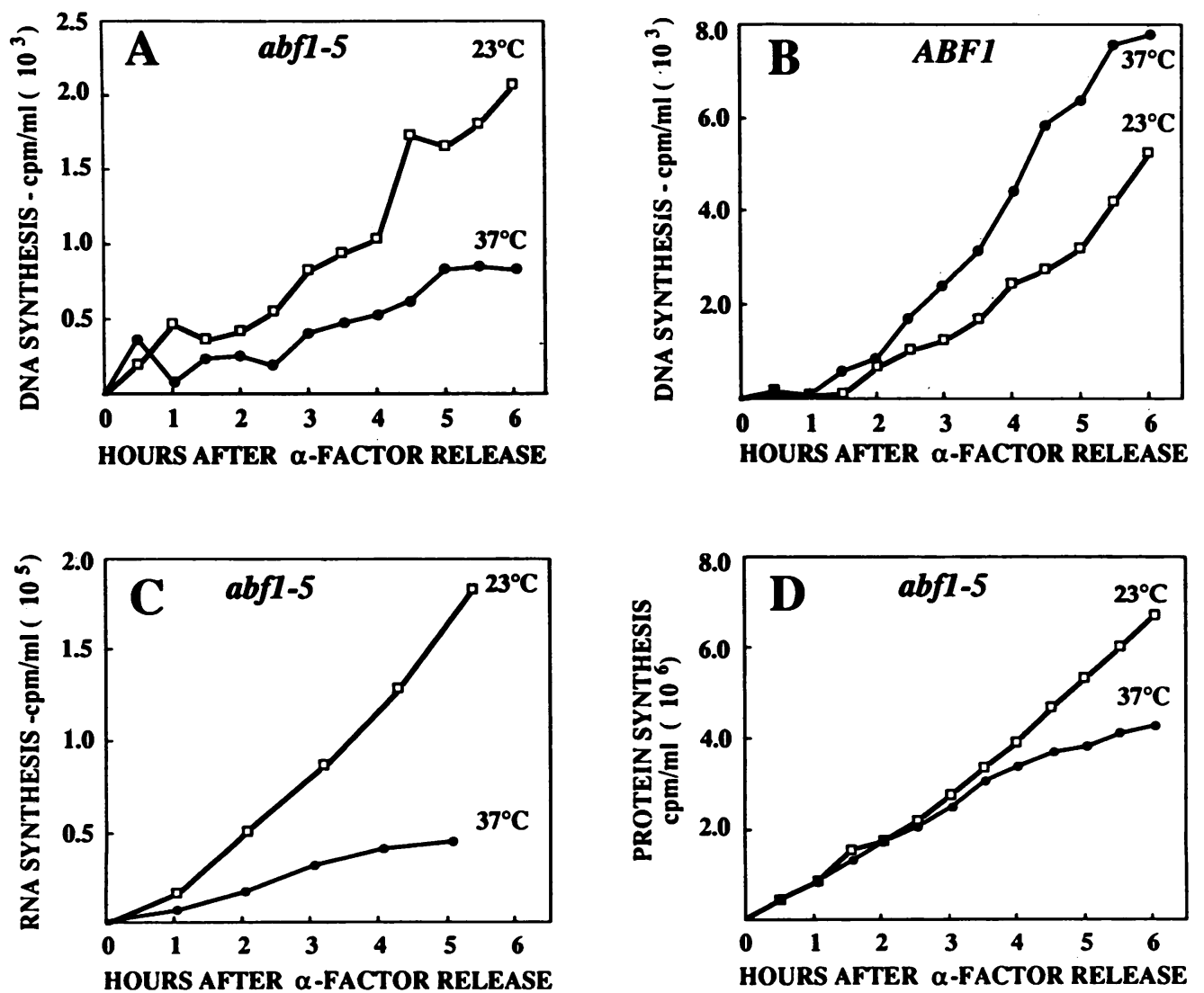

FIG. 6. DNA, RNA, and protein synthesis in $\alpha$-factor-synchronized abfl-5 cells. JCA55 (barl-1 abfl-5) and JCA50 (barl-1 ABFI) strains were arrested at START by treatment with $0.3 \mu \mathrm{g}$ of $\alpha$-factor per $\mathrm{ml}$ as described in Materials and Methods. Following the removal of $\alpha$-factor, macromolecular synthesis was measured in cells incubated at $23^{\circ} \mathrm{C}(\square)$ or $37^{\circ} \mathrm{C}(O)$. The time courses of $\left[^{3} \mathrm{H}\right]$ uracil incorporation into DNA are shown for JCA55 (A) and JCA50 (B) cells. $\left[{ }^{3} \mathrm{H}\right]$ uracil incorporation into RNA (C) and Trans ${ }^{35} \mathrm{~S}$ (methionine and cysteine) incorporation into protein (D) are shown for JCA55 cells. Each point represents the average of duplicate determinations.

The less than wild-type level of ongoing synthesis at $37^{\circ} \mathrm{C}$ could be due to reduced rates in all cells; alternatively, some cells could complete replication of replicons already initiated at the time of the shift-up and arrest in $G_{2}$, while other cells in the population fail to initiate any DNA synthesis and arrest in $G_{1}$ phase. The latter interpretation is supported by the results of flow cytometric analysis. As shown in Fig. 5, $a b f 1-5$ cells arrested at $37^{\circ} \mathrm{C}$ consisted of two discrete populations, one in $G_{1}$ and one in $G_{2}$. A more direct test of the effect on initiation versus elongation of DNA synthesis is discussed below.

Effects of the abf1(Ts) alleles in synchronously growing cultures. To examine whether the initiation of DNA replication was affected in the abfl(Ts) mutants, DNA synthesis and cell cycle progression were monitored in cells synchronized with $\alpha$-factor. An abfl-5 barl culture incubated at the permissive temperature was treated with $\alpha$-factor until growth arrested at START. (The barl mutant was used in these studies to reduce the amount of $\alpha$-factor needed and thus prevent nonspecific toxicity.) The $\alpha$-factor was removed, and the cells were shifted to the nonpermissive temperature in media containing $\left[{ }^{3} \mathrm{H}\right]$ uracil. DNA synthesis rates in these cultures were found to be $50 \%$ of that seen in cultures released from $\alpha$-factor arrest at the permissive temperature (Fig. 6A). Furthermore, the magnitude of this defect is even greater when compared with DNA synthesis in a synchronized $A B F I$ strain, in which the incorporation

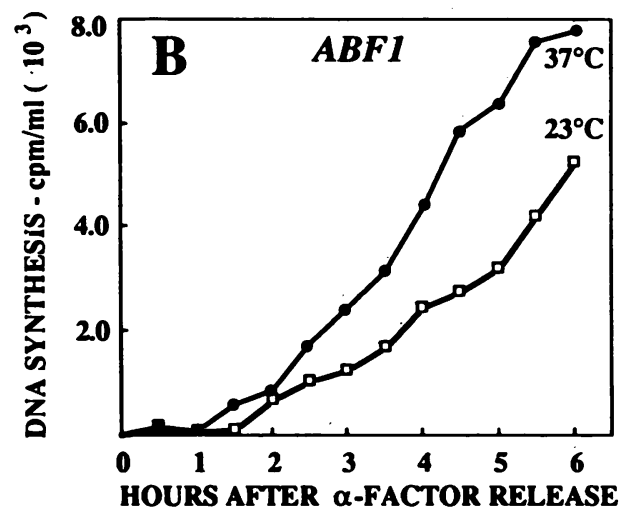




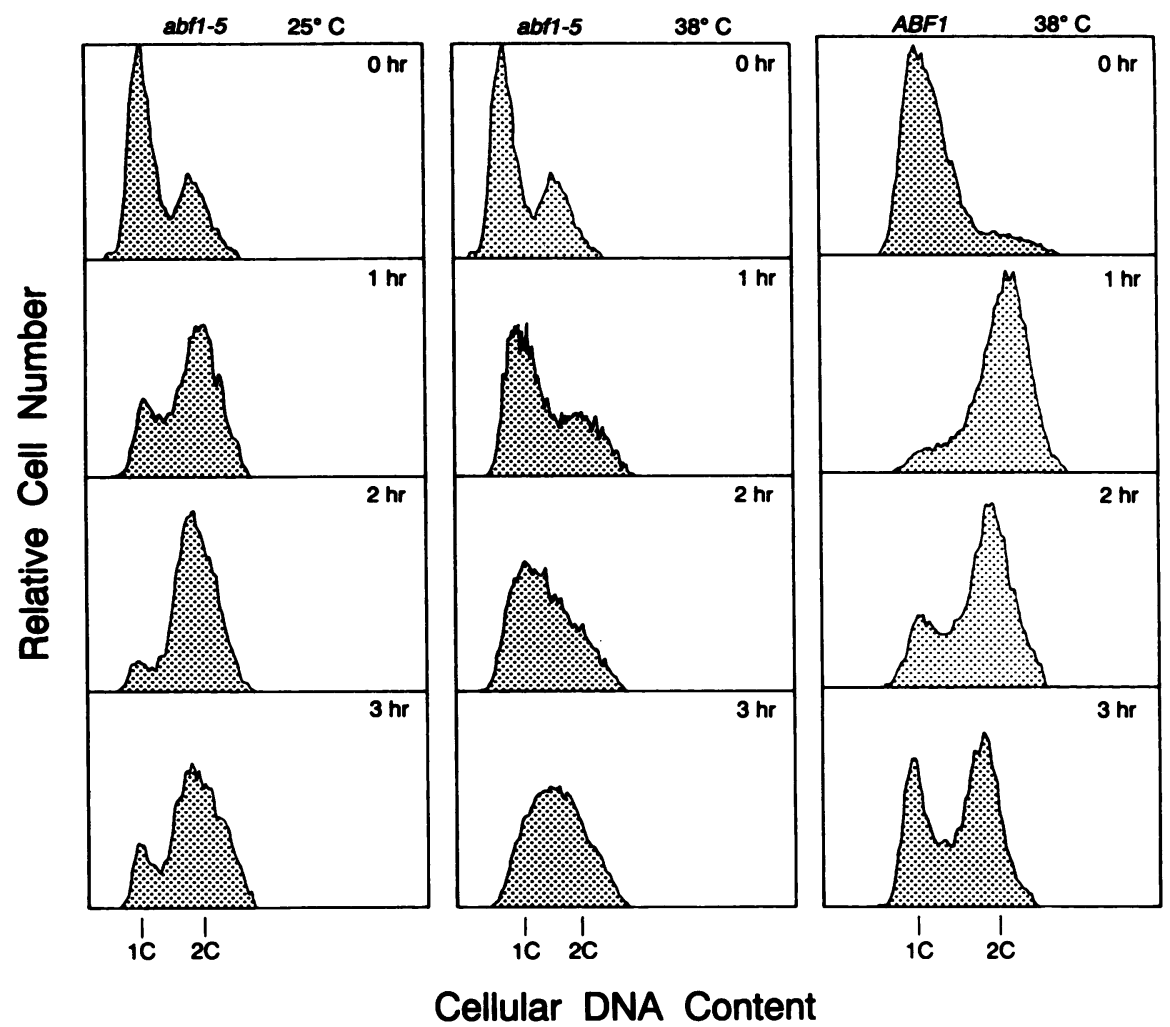

FIG. 7. Cell cycle progression of $\alpha$-factor-synchronized $a b f 1-5$ cells. JCA55 (barl-1 abfl-5) and JCA50 (barl-1 ABFl) strains were arrested with $\alpha$-factor as described in Materials and Methods. Following the removal of $\alpha$-factor, the cells were incubated at 25 or $38^{\circ} \mathrm{C}$ in YPD. At the indicated times, aliquots were removed and fixed with $70 \%$ ethanol, and cellular DNA was stained with propidium iodide as described in Materials and Methods. Shown are DNA histograms of the propidium iodide-stained cells determined by flow cytometry.

rate at $37^{\circ} \mathrm{C}$ was twice that seen at $23^{\circ} \mathrm{C}$ (Fig. 6B). Cells that were arrested with $\alpha$-factor, released at the nonpermissive temperature for 1 or $2 \mathrm{~h}$, and shifted back to the permissive temperature recovered the ability to synthesize DNA at the same rate as was observed in cells initially released at the permissive temperature (data not shown), indicating that the replication defect was reversible and cannot be attributable to a loss of cell viability. By comparison with other mutants involved in DNA replication, this defect was greater than the DNA replication defect of a $c d c 2$ mutant, which carries a defective DNA polymerase $\delta(20)$.

Similar incorporation time courses were carried out to measure RNA and protein synthesis levels in synchronized abfl-5 cells at the nonpermissive temperature. In these cultures, RNA synthesis was inhibited to $35 \%$ of the level seen at the permissive temperature (Fig. $6 \mathrm{C}$ ), consistent with the effects seen in asynchronous cultures. In contrast, protein synthesis rates were identical for several hours in the synchronized $a b f l-5$ cultures incubated at nonpermissive and permissive temperatures (Fig. 6D). As was observed for DNA synthesis (Fig. 6B), synchronized $A B F 1$ cells released at $37^{\circ} \mathrm{C}$ synthesized RNA and protein at approximately twice the rate measured at $23^{\circ} \mathrm{C}$ (data not shown).

Because RNA and to a lesser extent protein synthesis are affected in $a b f 1-5$ cultures at the nonpermissive temperature, it is difficult to make conclusions as to the direct role of ABF1 in DNA replication. However, the extent and reversibility of the DNA synthesis defect suggest that some or all of these cells fail to initiate and progress through $S$ phase efficiently as the result of the loss of ABF1 function. This hypothesis was supported by flow cytometric analysis of $a b f 1-5$ cells synchronized with $\alpha$-factor and then released at either the permissive or nonpermissive temperature. Figure 7 shows that $\alpha$-factor treatment resulted in arrest of approximately $70 \%$ of the $a b f 1-5$ cells at START with a $1 C$ content of DNA. Following the removal of $\alpha$-factor, cultures incubated at the permissive temperature for $2 \mathrm{~h}$ had progressed through $S$ phase and into $G_{2}(2 C$ DNA content). Cultures incubated at the nonpermissive temperature recovered from $\alpha$-factor arrest but initiated and progressed through $S$ phase inefficiently, consistent with the defect in DNA synthesis seen in Fig. 6. As a result, by $3 \mathrm{~h}$ after release from $\alpha$-factor arrest, less than half of the $G_{1}$ cells showed an increase in DNA content. A precise estimate is not possible because of broadening of the $G_{1}$ and $G_{2}$ peaks for $a b f l(T s)$ cells arrested at the nonpermissive temperature (data not shown). The isogenic $A B F 1$ barl strain synchronized in the same manner progressed efficiently through the cell cycle at both $25^{\circ} \mathrm{C}$ (not shown) and $38^{\circ} \mathrm{C}$ (Fig. 7).

Transcriptional activation function of the ABF1 binding site is defective in an abf1-1 strain. Sequence data base searches have revealed that as many as $\mathbf{8 0}$ yeast genes contain ABF1 binding sites within their promoters. Several laboratories have shown by mutational analysis that these sites play an important role in both positive and negative regulation of gene expression $(4,6,9,16,21,22,27,35,36,38,47)$. Furthermore, when the ABF1 binding site from the $H M R E$ silencer was inserted into a promoter lacking a functional UAS, fourfold transcriptional activation was observed $(4,9)$. However, when UAS activity was determined for ABF1 
TABLE 3. UAS activity in an abfl-1 strain

\begin{tabular}{|c|c|c|c|c|c|}
\hline \multirow{2}{*}{$\begin{array}{l}\text { UAS } \\
\text { element }\end{array}$} & \multirow[b]{2}{*}{ Strain } & \multicolumn{2}{|c|}{ Semipermissive temp $\left(30^{\circ} \mathrm{C}\right)$} & \multicolumn{2}{|c|}{ Permissive temp $\left(25^{\circ} \mathrm{C}\right)$} \\
\hline & & $\begin{array}{l}\text { B-Galactosidase } \\
\text { sp act (U/mg) }\end{array}$ & $\begin{array}{c}\text { UAS } \\
\text { activity }^{a}\end{array}$ & $\begin{array}{l}\text { B-Galactosidase } \\
\text { sp act (U/mg) }\end{array}$ & $\begin{array}{c}\text { UAS } \\
\text { activity }\end{array}$ \\
\hline None & $A B F 1$ & $1.42 \pm 0.05$ & 1 & $0.58 \pm 0.05$ & 1 \\
\hline \multirow[t]{2}{*}{ ABS } & $a b f 1-1$ & $1.82 \pm 0.04$ & 1.1 & $1.88 \pm 0.15$ & 3.1 \\
\hline & $A B F I$ & $4.97 \pm 0.25$ & 3.5 & $3.16 \pm 0.19$ & 5.4 \\
\hline ARE & $a b f 1-1$ & $319 \pm 30$ & 194 & $445 \pm 11$ & 734 \\
\hline
\end{tabular}

${ }^{a}$ Ratio of $\beta$-galactosidase activity in a strain carrying the $U A S$-cycl-lacZ construct versus the pLGAB (no UAS) plasmid.

binding sites that had a 20-fold range in affinity for purified $A B F 1$, no correlation between the ABF1 relative binding affinity in vitro and UAS activity of these sites was observed (9). Therefore, it is not clęar whether UAS function was due to the direct action of $A B F 1$ or to other factors that might bind to these sites. To address the role of ABF1 in transcriptional activation, we tested the UAS function of the ABF1 binding site in an abfl-1 strain. An oligonucleotide (designated ABS) corresponding to the ABF1 binding site at $A R S I$ was inserted into the UAS-less $C Y C l$ promoter-lacZ fusion gene of the pLG $\Delta B$ plasmid. This plasmid was used to transform $a b f 1-1$ and wild-type strains, and transformants maintained at permissive and semipermissive temperatures were assayed for $\beta$-galactosidase activity (Table 3 ). Basal levels of $\beta$-galactosidase activity were identical in $a b f 1-1$ and wild-type strains carrying the $\mathrm{pLG} \Delta \mathrm{B}$ plasmid lacking the UAS. When the ABS oligonucleotide was inserted in this plasmid, a three- to fivefold increase in $\beta$-galactosidase activity was observed in both the $a b f 1-1$ and wild-type strains maintained at $25^{\circ} \mathrm{C}$, consistent with the weak UAS activity of the ABF1 binding site reported previously. However, the ABF1 binding site failed to activate transcription above basal levels in the $a b f l-l$ strain grown at the semipermissive temperature. Wild-type cells showed a threefold increase in $\beta$-galactosidase activity under these semipermissive conditions.

ABF1 binding sites are found in the promoters of genes encoding subunits of RNA polymerases, translational initiation factors, and ribosomal proteins $(21,22)$. Thus, the $a b f 1-1$ allele may be affecting $\beta$-galactosidase activity indirectly by altering levels of the transcriptional or translational machinery. Additional effects of the pLG $\triangle B$ plasmid levels also may result in lower $\beta$-galactosidase activity in this strain. To address whether the $a b f 1-1$ allele is indirectly affecting induction of $\beta$-galactosidase activity at the semipermissive temperature, we assayed the UAS activity of the binding site of the yeast transcription factor yAP1. Previous studies have shown that this site, called the ARE oligonucleotide, acts as a strong UAS element and that yAP1 activates ARE-CYCl:lacZ reporter gene expression in a temperature-independent manner $(37,54)$. Unlike the ABF1 binding site, the ARE oligonucleotide acted as a strong UAS in the $a b f 1-1$ strain at the semipermissive temperature, increasing $\beta$-galactosidase activity 200 -fold over basal levels. However, ARE-UAS function was reduced to $60 \%$ of that seen in the wild-type strain, suggesting some ABSindependent effects of the $a b f 1-1$ allele on full induction of $\beta$-galactosidase activity. This effect was not observed at the permissive temperature, at which ARE-UAS function was equivalent in the $a b f l-1$ and wild-type strains. These results suggest that the complete temperature-dependent loss of
ABS-UAS function in the $a b f 1-1$ strain is due at least in part to the action of $A B F 1$ on transcriptional activation at this site.

Mapping of essential regions of ABF1 by using abfi(Ts) alleles. To begin to address structure-function relationships for $A B F 1$, we cloned a series of $3^{\prime}$ deletions of the $A B F 1$ coding sequence into an ARS-CEN-URA3 plasmid and introduced these constructs into the $a b f 1-1$ strain. Transformants were used to determine whether C-terminal regions of ABF1 were required for DNA binding activity and for complementation of the $a b f 1-1$ temperature-sensitive growth phenotype. As shown in Fig. 2A, extracts from abfl-1 strains grown at the permissive temperature did not contain measurable $\mathrm{ABF} 1$ binding activity. When a full-length $A B F 1$ gene (construct $\mathrm{H} 2.6$ ) or a 500 -bp deletion in the $3^{\prime}$ end of $A B F I$ (construct $\mathrm{H} 2.1$ ) was introduced into this strain, extracts showed ABF1-specific DNA binding activity, whereas no DNA binding was observed when deletions of 1 $\mathrm{kb}$ (or larger) from the $3^{\prime}$ end of $A B F 1$ were tested (Fig. 8). These results indicate that the C-terminal region of the protein is dispensable for DNA binding activity in vitro and are consistent with the findings of similar DNA binding

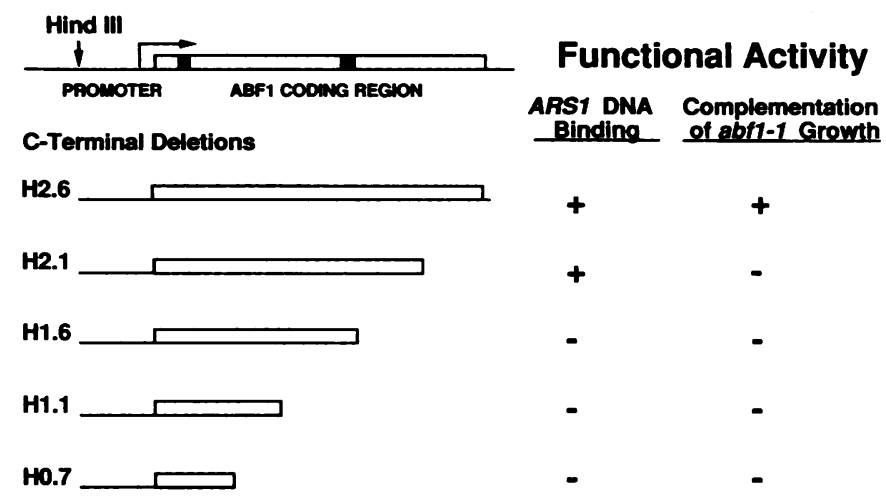

FIG. 8. Structure-function analysis of the $A B F l$ gene. A series of URA3-ARS-CEN plasmids bearing $3^{\prime}$ deletions in the $A B F 1$ gene was constructed as described in Materials and Methods. The bars represent the $A B F I$ coding region for the intact and deletion constructs. The solid block represents the putative metal binding motif; the striped block represents the basic region described in the text. The normal $A B F 1$ promoter and transcriptional termination sequences are at the $5^{\prime}$ and $3^{\prime}$ ends, respectively, of the deleted $A B F 1$ genes. Following introduction into JCA31 (abfl-1 ura3-52) cells, the deletion constructs were tested for the ability to bind an oligonucleotide (element B) for the ABF1 binding site at $A R S 1$ as assayed by gel retardation (59) and for complementation of the $a b f 1-1$ growth defect at $32^{\circ} \mathrm{C}$. 
studies on bacterially produced ABF1 (34). None of the C-terminal deletion constructs were able to complement the growth defect of the $a b f l-1$ strain at $32^{\circ} \mathrm{C}$ (the minimum nonpermissive temperature), indicating that ABF1 DNA binding activity alone is not sufficient to provide all of the essential functions mediated by $\mathrm{ABF} 1$ in vivo.

\section{DISCUSSION}

Mutational analysis of several ARSs previously suggested a role for ABF1 in DNA replication by defining the ABF1 binding site as a cis-acting element important though not essential for ARS activity. For example, Diffley and Stillman (24) showed that deletion of the ABF1 binding site at ARSI resulted in a small but detectable decrease in plasmid stability. This defect was exaggerated when similar deletions were assayed under suboptimal growth conditions (galactose as a carbon source) (69). Mutagenesis of the ABF1 binding site at the HMRE ARS gave more ambiguous results. In the case of a deletion, a large defect in plasmid stability was observed (3), while a point mutation in the ABF1 binding site showed no detectable effects (47). Linker-scanning mutations in domain B of ARS121 that removed the ABF1 binding site also resulted in a threefold decrease in plasmid stability (74). In addition, the ABF1 binding site has been shown to act as an orientation- and position-independent enhancer of ARS activity at $A R S 121$ (73). It is intriguing that the degree of dependence of ARS activity on the ABF1 binding site correlated with $A B F 1$ binding affinity at these ARSs. For instance, purified $A B F 1$ has a 5- to 10-fold higher affinity for $A R S 121$ than for ARSI or the HMRE ARS (30), and ABF1 binding site mutations have a more deleterious effect on $A R S 121$ than on $A R S 1$. These findings further imply that occupancy of the ABF1 binding site is important for ARS activity.

Based on the temperature-dependent defect in ARS-CEN plasmid stability, we have demonstrated a role of ABF1 on ARS activity in the $a b f l$ (Ts) strains. The magnitude of this defect for $A R S 1$ and $A R S 121$ plasmids correlated with the effect of ABF1 binding site mutations at these ARSs reported previously. The stability of the H4ARS plasmid was also slightly defective in the $a b f l$ (Ts) strains. High-affinity ABF1 binding sites have not been reported for this ARS, suggesting that the small defect in plasmid stability observed may be an indirect effect or mediated through low-affinity ABF1 binding sites. Several other functional ARSs, including the $H 2 B$ ARS and the $H M L E$ ARS, apparently lack high-affinity ABF1 binding sites (8). Thus, it seems likely that the requirement for $A B F 1$ can be fulfilled by other cis-acting elements at these ARSs and (under optimal growth conditions) at $A R S I$.

Minichromosome maintenance-defective $(\mathrm{mcm})$ mutants representing 18 different complementation groups that result in decreased stability of $A R S-C E N$ plasmids have been isolated $(32,50)$. Like the $a b f l$ (Ts) mutants, several of these mutants ( $\mathrm{mcm} 1, \mathrm{mcm} 2$, and $\mathrm{mcm} 3$ ) showed an ARS-specific defect, suggesting a role in plasmid replication rather than segregation or other functions required for stability (32). However, the $a b f l(T s)$ mutants clearly have an ARS specificity different from that of the $\mathrm{mcml}, \mathrm{mcm} 2$, or $\mathrm{mcm} 3$ mutants. In fact, $A R S 121$ plasmids are unstable while $A R S 1$ plasmids are stable in the abfl(Ts) strain at the nonpermissive temperature, whereas exactly the opposite pattern of plasmid stability is observed in the $\mathrm{mcm}$ mutants. Although direct roles of the $\mathrm{mcm}$ mutants in ARS function remain to be demonstrated, these findings suggest that $\mathrm{ABF} 1$ and the
MCM proteins may act independently through different functional elements at different ARSs.

Like ABF1, MCM1 is a transcription factor that is involved in activation or repression of transcription $(1,46,57)$. At least one other well-defined transcription factor has been implicated in ARS function as a result of a search for mutations that increased the stability of plasmids that carried the $H O$ ARS, in which a point mutation caused increased plasmid loss (48). Of three genes identified, RARI, RAR3, and $R A R 5, R A R 3$ has been shown to encode a protein identical to the GAL11/SPT13 transcription factor (48). GAL11/SPT13 has been shown to be a general transcription factor that acts at a large number of genes and to have both activator and repressor function. Thus, at least two transcription factors in addition to ABF1 have been shown to affect ARS function, at least as measured on plasmids, and a picture of ARS organization in which a core activating sequence is influenced by association with different enhancers is emerging.

While the roles of $A B F 1$ binding sites and mutations affecting them have been evaluated on $A R S$ plasmids, the effects of ABF1 site mutations on origins of replication in their chromosomal location has not yet been investigated by two-dimensional gel analysis. However, evaluation of DNA replication in $a b f 1$ (Ts) mutants suggested that $\mathrm{ABF} 1$ plays a role in the initiation of chromosomal DNA replication. Conclusions as to whether this is a direct role are limited by the fact that the $a b f 1-5$ mutations also affect transcription in these strains. Synchronized $a b f 1-5$ cultures recovered from $\alpha$-factor arrest and initiated DNA synthesis at the same time as did wild-type cells (Fig. 6) but failed to progress through $S$ phase (Fig. 7) and showed reduced rates of DNA synthesis at the nonpermissive temperature. This defect was reversible when the abfl-5 cultures were shifted down to the permissive temperature. The residual DNA synthesis observed in the abfl-5 strain may be due to initiation at replication origins not dependent on $\mathrm{ABF} 1$, mitochondrial DNA synthesis, or leakiness of this allele. Comparison of DNA synthesis rates in the asynchronous abfl(Ts) cultures suggests that ongoing DNA synthesis can continue in these cells at the nonpermissive temperature. Furthermore, when synchronized $a b f l-5$ cells were allowed to progress into $S$ phase for 1 or $2 \mathrm{~h}$ and then shifted to the nonpermissive temperature, rates of DNA synthesis and cell cycle progression were intermediate to those seen at the permissive and nonpermissive temperatures (58). These results may indicate that DNA synthesis initiated prior to the temperature shift can continue either at a slightly slower rate or at the same rate while further initiation at late-replicating origins is inhibited; alternatively, some cells may fail to initiate altogether, depending on the stage of the cell cycle when the nonpermissive condition is introduced. The initiation defect at $37^{\circ} \mathrm{C}$ in the $a b f 1-5$ mutant appears to be greater than expected on the basis of the variable requirement for ABF1 at ARS elements observed in the plasmid stability assays. The necessity of carrying out the ARS stability assays at the semipermissive temperature may account for this finding. Alternatively, ABF1 has greater or lesser importance at each ARS, depending on the other proteins that interact there. It will be of great interest to examine the sequence requirements for chromosomal origins of replication as well as origin utilization in an abfl(Ts) strain.

It has been proposed that ABF1 plays a role in the transcriptional activation or repression of as many as $\mathbf{8 0}$ genes. Given that there are five ABF1 binding sites in the promoter of the $A B F I$ gene, this protein may even regulate 
its own expression $(34,58)$. We found that the ability of the ABF1 binding site to act as a UAS element in the CYCI-lacZ test plasmid was completely temperature sensitive in an $a b f 1-1$ strain, demonstrating a direct role of ABF1 in transcriptional activation. The specific effect of the $a b f 1$ (Ts) alleles on the transcription of yeast genes that ABF1 is thought to control, including repression of the silent matingtype loci, is currently under investigation. Recently, Kurtz and Shore (49) used a similar approach to demonstrate that RAP1 regulates transcriptional activation of $M A T \alpha$ genes and transcriptional repression at $H M R$. In addition to the effects on specific transcriptional activation, we observed a significant defect in general RNA synthesis in the abfl(Ts) strains at the nonpermissive temperature. This defect may be the result of an ABF1 function directly at the 35S rRNA gene. $A B F 1$ is likely to interact with a protein recognition site (the REB2 site) found in the transcriptional enhancer/ terminator element of the rRNA repeat $(17,53)$. However, the functional role of this site in enhancer activity has yet to be investigated. Alternatively, since ABF1 binding sites are found in the promoters of genes encoding subunits of RNA polymerases I and III (22), it is possible that the defect in RNA synthesis is due to a reduction in RNA polymerase activity. ABF1 also may affect transcription of genes that control translation, including those encoding ribosomal proteins, translational initiation factors, and aminoacyl-tRNA synthetases (see reference 21 for references); however, little or no decrease in protein synthesis rates was observed in the $a b f 1$ (Ts) mutants at the nonpermissive temperature.

How a single DNA-binding protein can regulate a number of important nuclear processes is currently of great interest. As mentioned above, ABF1 is functionally similar to RAP1 and MCM1. These proteins contribute to repression or activation of transcription, depending on the context of their binding sites $(1,10,46,57,61)$. In addition, MCM1 may function in the initiation of DNA replication at a subset of ARS elements (57), and RAP1 binds to and controls the length of poly $\left(C_{1-3} A\right)$ tracts at telomeres $(10,50)$. While it remains possible that these factors act through some general mechanism such as nucleosome exclusion or DNA bending at functionally distinct sites, it appears most likely that they mediate various functions by specific combinatorial interactions with other structural or regulatory proteins in a context-dependent manner. In support of this hypothesis, recent mutational analysis indicated that different domains of these proteins are required for different functions $(19,49)$. For example, the DNA binding domain of MCM1 is sufficient for this protein's essential function, the minichromosome maintenance phenotype, and transcriptional repression of $\alpha$-specific genes (19). Additional domains are required for transcriptional regulation of $\alpha$-specific genes. Unlike MCM1, structure-function studies of the $A B F I$ gene clearly demonstrate that the DNA binding domain alone cannot perform all of ABF1's essential functions. Through complementation of the phenotypes observed in the $a b f l$ (Ts) mutants, we hope to further define the domains of ABF1 responsible for ARS function and transcriptional control. It is also possible that ABF1 exists in several functionally distinct states. We have recently found that $A B F 1$ is a phosphoprotein with at least four different forms (64). ABF1 phosphorylation states vary with different growth conditions and correlate with the expression of $\mathrm{ABF} 1-$ regulated genes such as $\mathrm{COX6}$. In addition, ABF1 containing protein- $C O X 6$ promoter DNA complexes have different electrophoretic mobilities, depending of the phosphorylation state of $A B F 1$. These results suggest that interaction with other factors may be dependent on the phosphorylated state of ABF1 (64).

Several viral and mammalian transcription factors have been found to activate viral DNA replication through interactions at auxiliary binding sites in the viral origin (see reference 23 for a review). These proteins appear to function in DNA replication by a variety of mechanisms, including nucleosome exclusion from the replication origin (18), facilitated interactions of the initiator protein with its binding site (52), and activation of the DNA unwinding activity of the initiator (33). At the ARSI origin, the ABF1 binding site is found at the boundary of a region of nucleosome-free chromatin, suggesting that ABF1 may affect local chromatin structure $(65,68)$. Furthermore, alterations in nucleosome position at $A R S I$ have measurable effects on ARS activity (65). Correlations between the effects of ABF1 on chromatin structure and changes in ARS activity (or transcription control of adjacent genes) could readily be examined by using the $a b f($ Ts) strains. In addition, the development of in vitro DNA replication assays would be useful in determining whether ABF1 acts through a mechanism similar to that of viral replication or transcription factors.

\section{ACKNOWLEDGMENTS}

We thank Martin Budd for helpful discussions on generating temperature-sensitive mutants. We are grateful to Shlomo Eisenberg, Mitchell Smith, Scott Moye-Rowley, Carl Parker, Ambrose Jong, Martin Budd, and Karen Sitney for providing plasmids and strains used in this study. We also thank Shelley Diamond and Pat Koen for expert assistance in the flow cytometric analysis and Karen Oegema for assistance in cloning the 3'ABFI deletions.

This work was supported by USPHS grant GM25508, a Procter and Gamble postdoctoral fellowship to P.R.R., and NIH training grant 5-T32-GM07616 (S.E.).

\section{REFERENCES}

1. Bender, A., and G. F. Sprague, Jr. 1987. MAT $\alpha 1$ protein, a yeast transcription activator, binds synergistically with a second protein to a set of cell-type-specific genes. Cell 50:681-691.

2. Biswas, E. E., M. J. Stefanec, and S. B. Biswas. 1990. Molecular cloning of a gene encoding an ARS binding factor from the yeast Saccharomyces cerevisiae. Proc. Natl. Acad. Sci. USA 87: 6689-6692.

3. Bouton, A. H., and M. M. Smith. 1986. Fine-structure analysis of the DNA sequence requirements for autonomous replication of Saccharomyces cerevisiae plasmids. Mol. Cell. Biol. 6:2354 2363.

4. Brand, A. H., G. Micklem, and K. Nasmyth. 1987. A yeast silencer contains sequences that can promote autonomous plasmid replication and transcriptional activation. Cell 51:709-719.

5. Brewer, B. J., and W. L. Fangman. 1987. The localization of replication origins of ARS plasmids in S. cerevisiae. Cell 51:463-471.

6. Brindle, P. K., J. P. Holland, C. E. Willett, M. A. Innis, and M. J. Holland. 1990. Multiple factors bind the upstream activation sites of the yeast enolase genes ENO1 and ENO2: ABF1 protein, like repressor activator protein RAP1, binds cis-acting sequences which modulate repression or activation of transcription. Mol. Cell. Biol. 10:4872-4885.

7. Broach, J. R., Y.-Y. Li, J. Feldman, M. Jayaram, K. A. Nasmyth, and J. B. Hicks. 1983. Localization and sequence analysis of yeast origins of DNA replication. Cold Spring Harbor Symp. Quant. Biol. 47:1165-1173.

8. Buchman, A. R., W. J. Kimmerly, J. Rine, and R. D. Kornberg. 1988. Two DNA-binding factors recognize specific sequences at silencers, upstream activating sequences, autonomously replicating sequences, and telomeres in Saccharomyces cerevisiae. Mol. Cell. Biol. 8:210-225.

9. Buchman, A. R., and R. D. Kornberg. 1990. A yeast ARSbinding protein activates transcription synergistically in combi- 
nation with other weak activating factors. Mol. Cell. Biol. 10:887-897.

10. Buchman, A. R., N. F. Lue, and R. D. Kornberg. 1988. Connections between transcriptional activators, upstream activation sequences, autonomously replicating sequences, and telomeres in Saccharomyces cerevisiae. Mol. Cell. Biol. 8:210-225.

11. Budd, M., and J. L. Campbell. 1987. Temperature-sensitive mutations in the yeast DNA polymerase I gene. Proc. Natl. Acad. Sci. USA 84:2838-2842.

12. Budd, M. E., K. D. Wittrup, J. E. Bailey, and J. L. Campbell. 1989. DNA polymerase $I$ is required for premeiotic DNA replication and sporulation but not for X-ray repair in Saccharomyces cerevisiae. Mol. Cell. Biol. 9:365-376.

13. Busby, S., M. Irani, and B. deCrombruggie. 1982. Isolation of mutant promoter in the Escherichia coli galactose operon using local mutagenesis of cloned DNA fragments. J. Mol. Biol. 154:197-209.

14. Campbell, J. L., and C. S. Newlon. 1991. Chromosomal DNA replication, p. 41-146. In J. Broach, E. E. Jones, and J. Pringle (ed.), The molecular and cellular biology of the yeast Saccharomyces, vol. 1. Cold Spring Harbor Laboratory, Cold Spring Harbor, N.Y.

15. Celniker, S. E., K. Sweder, F. Srienc, J. E. Bailey, and J. L. Campbell. 1984. Deletion mutations affecting autonomously replicating sequence ARS1 of Saccharomyces cerevisiae. Mol. Cell. Biol. 4:2455-2466.

16. Chambers, A., C. Stanway, J. S. H. Tsang, Y. Henry, A. J. Kingsman, and S. M. Kingsman. 1990. ARS binding factor 1 binds adjacent to RAP1 at the UASs of the yeast glycolytic genes $P G K$ and $P Y K 1$. Nucleic Acids Res. 18:5393-5399.

17. Chasman, D. I., N. F. Lue, A. R. Buchman, J. W. LaPointe, Y. Lorch, and R. Kornberg. 1990. A yeast protein that influences the chromatin structure of $\mathrm{UAS}_{\mathrm{G}}$ and functions as a powerful auxiliary gene activator. Genes Dev. 4:503-514.

18. Cheng, L., and T. J. Kelly. 1989. Transcriptional activator nuclear factor I stimulates the replication of SV40 minichromosomes in vivo and in vitro. Cell 59:541-551.

19. Christ, C., and B.-K. Tye. 1991. Functional domains of the yeast transcription/replication factor MCM1. Genes Dev. 5:751-763.

20. Conrad, M. N., and C. S. Newlon. 1983. Saccharomyces cerevisiae $c d c 2$ mutants fail to replicate approximately one-third of their nuclear genome. Mol. Cell. Biol. 3:1000-1012.

21. Della Seta, F., S.-A. Dafré, C. Marck, B. Santoro, C. Presutti, S. Sentenac, and I. Bozzoni. 1990. The ABF1 factor in the transcriptional activator of the L2 ribosomal protein genes in Saccharomyces cerevisiae. Mol. Cell Biol. 10:2437-2441.

22. Della Seta, F., I. Treich, J.-M. Buhler, and A. Sentenac. 1990. ABF1 binding sites in yeast RNA polymerase genes. J. Biol. Chem. 265:15168-15175.

23. DePamphilis, M. L. 1988. Transcriptional elements as components of eukaryotic origins of DNA replication. Cell 52:635-638.

24. Diffley, J. F. X., and B. Stillman. 1988. Purification of a yeast protein that binds to origins of DNA replication and a transcriptional silencer. Proc. Natl. Acad. Sci. USA 85:2120-2124.

25. Difiley, J. F. X., and B. Stillman. 1989. Similarity between the transcriptional silencer binding proteins $\mathrm{ABF1}$ and RAP1. Science 246:1034-1038.

26. Dolan, J. W., and S. Fields. 1990. Overproduction of the yeast STE12 protein leads to constitutive induction. Genes Dev. 4:492-502.

27. Dorsman, J. C., M. M. Doorenbosch, C. T. C. Maurer, J. H. deWinde, W. H. Mager, R. J. Planta, and L. A. Grivell. 1989. Identification of two factors which bind to the upstream sequences of a number of nuclear genes coding for mitochondrial proteins and to genetic elements important for cell division in yeast. Nucleic Acids Res. 16:7287-7301.

28. Dorsman, J. C., J. C. Gozdzickajozefiak-A, W. C. Vanheeswijk, and L. A. Grivell. 1991. Multifunctional DNA proteins in yeast-the factors GF1 and GFII are identical to the ARSbinding factor ABFI and the centromere-binding factor CPF1, respectively. Yeast 7:401-412.

29. Eisenberg, S., C. Civalier, and B. K. Tye. 1988. Specific interaction between a Saccharomyces cerevisiae protein and a DNA element associated with certain automonously replicating sequences. Proc. Natl. Acad. Sci. USA 85:743-746.

30. Francesconi, S. C., and S. Eisenberg. 1989. Purification and characterization of OBF1: a Saccharomyces cerevisiae protein that binds to automonously replicating sequences. Mol. Cell. Biol. 9:2906-2913.

31. Francesconi, S. C., and S. Eisenberg. 1991. The multifunctional protein $\mathrm{OBF} 1$ is phosphorylated at serine and threonine residues in Saccharomyces cerevisiae. Proc. Natl. Acad. Sci. USA 88:4089-4093.

32. Gibson, S., R. Surosky, P. Sinha, G. Maine, and B.-K. Tye. 1987. Complexity of the enzyme system for the initiation of DNA replication in yeast. ICN-UCLA Symp. Mol. Cell. Biol. 47:347354.

33. Gutirrez, C., Z.-S. Guo, J. Roberts, and M. L. DePamphilis. 1990. Simian virus 40 origin auxiliary sequences facilitate T-antigen binding but strongly facilitate DNA unwinding. Mol. Cell. Biol. 10:1719-1728.

34. Halfter, H., B. Kavety, J. Vandekerckhove, F. Kiefer, and D. Gallwitz. 1989. Sequence, expression and mutational analysis of BAP1, a transcriptional activator and $A R S 1$-binding protein of the yeast Saccharomyces cerevisiae. EMBO J. 8:4265-4272.

35. Halfter, H., U. Müller, E.-L. Winnacker, and D. Gallwitz. 1989. Isolation and DNA-binding characteristics of a protein involved in transcription activation of two divergently transcribed, essential yeast genes. EMBO J. 8:3029-3037.

36. Hamil, K. G., H. G. Nam, and H. M. Fried. 1988. Constitutive transcription of yeast ribosomal protein gene $T C M l$ is promoted by uncommon cis- and trans-acting elements. Mol. Cell. Biol. 8:4328-4342.

37. Harshman, K. D., W. S. Moye-Rowley, and C. Parker. 1988. Transcriptional activation by the SV40 AP-1 recognition element in yeast is mediated by a factor similar to AP-1 that is distinct from GCN4. Cell 53:321-330.

38. Herruer, M. H., W. H. Mager, T. M. Doorenbosch, P. L. M. Wessels, T. M. Wassenaar, and R. J. Planta. 1989. The extended promoter of the gene encoding ribosomal protein S33 in yeast consists of multiple protein binding elements. Nucleic Acids Res. 17:7427-7439.

39. Hofmann, J. F.-X., and S. M. Gasser. 1991. Identification and purification of a protein that binds the yeast ARS consensus sequence. Cell 64:951-960.

40. Huberman, J. A., L. D. Spotila, K. A. Nawotka, S. M. EiAssouli, and L. R. Davis. 1987. The in vivo replication origin of the yeast $2 \mu \mathrm{m}$ plasmid. Cell 51:473-481.

41. Huberman, J. A., J. Zhu, L. R. Davis, and C. S. Newlon. 1988. Close association of a DNA replication origin and an ARS element on chromosome III of the yeast Saccharomyces cerevisiae. Nucleic Acids Res. 16:6373-6384.

42. Ito, H., Y. Fukuda, K. Murata, and A. Kimura. 1983. Transformation of intact yeast cells treated with alkali ions. J. Bacteriol. 153:163-168.

43. Johnson, L. M., M. Synder, L. M. S. Chang, R. W. Davis, and J. L. Campbell. 1985. Isolation of the gene encoding yeast DNA polymerase I. Cell 43:369-377.

44. Jones, K. A., J. T. Kadonaga, P. J. Rosenfeld, T. J. Kelly, and R. Tjian. 1987. A cellular DNA-binding protein that activates eukaryotic transcription and DNA replication. Cell 48:79-89.

45. Kearsey, S. 1984. Structural requirements for the function of a yeast chromosomal replicator. Cell 37:299-307.

46. Keleher, C. A., S. Passmore, and A. D. Johnson. 1989. Yeast repressor $\alpha 2$ binds to its operator cooperatively with yeast protein Mcm1. Mol. Cell. Biol. 9:5228-5230.

47. Kimmerly, W., A. Buchman, R. Kornberg, and J. Rine. 1988. Roles of two DNA-binding factors in replication, segregation and transcriptional repression mediated by a yeast silencer. EMBO J. 7:2241-2253.

48. Kipling, D., C. Tambini, and S. E. Kearsey. 1991. ras mutations with increase artificial chromosome stability in Saccharomyces cerevisiae identify transcription and recombination proteins. Nucleic Acids Res. 19:1385-1391.

49. Kurtz, S., and D. Shore. 1991. RAP1 protein activates and silences transcription of mating-type in yeast. Genes Dev. 
5:616-628.

50. Lustig, A. J., S. Kurtz, and D. Shore. 1990. Involvement of the silencer and UAS binding protein RAP1 in regulation of telomere length. Science 250:549-553.

51. Maine, G. T., P. Sinha, and B.-K. Tye. 1984. Mutants of $S$. cerevisiae defective in the maintenance of minichromosomes. Genetics 106:365-385.

52. Mohr, I. J., R. Clark, S. Sun, E. J. Androphy, R. MacPherson, and M. R. Botchman. 1991. Targeting the E1 replication protein to the papillomavirus origin of replication by complex formation with the E2 transactivator. Science 250:1694-1698.

53. Morrow, B. E., S. R. Johnson, and J. R. Warner. 1989. Proteins that bind to the yeast rDNA enhancer. J. Biol. Chem. 264:90619068.

54. Nieto-Sotelo, J., G. Wiederrecht, A. Okuda, and C. S. Parker. 1990. The yeast heat shock transcription factor contains a transcriptional activation domain whose activity is repressed under nonshock conditions. Cell 62:807-817.

55. O'Neill, E. A., C. Fetcher, C. R. Burrow, N. Heintz, R. G. Roeder, and T. J. Kelly. 1988. Transcriptional factor OTF-1 is functionally identical to the DNA replication factor NF-III. Science 241:1210-1213.

56. Palzkill, T. G., and C. S. Newlon. 1988. A yeast replication origin consists of multiple copies of a small conserved sequence. Cell 43:441-450.

57. Passmore, S., R. Elbe, and B.-K. Tye. 1989. Saccharomyces cerevisiae protein involved in plasmid maintenance is necessary for mating of MAT $\alpha$ cells. J. Mol. Biol. 204:593-606.

58. Rhode, P. R., and J. L. Campbell. Unpublished results.

59. Rhode, P. R., K. S. Sweder, K. F. Oegema, and J. L. Campbell. 1989. The gene encoding ARS-binding factor $I$ is essential for the viability of yeast. Genes Dev. 3:1926-1939.

60. Schmidt, A. M. A., S. U. Herterich, and G. Krauss. 1991. A single-stranded DNA binding protein from $S$. cerevisiae specifically recognizes the T-rich strand of the core sequence of ARS elements and discriminates against mutant sequences. EMBO J. 10:981-985.

61. Shore, D., and K. Nasmyth. 1987. Purification and cloning of a DNA binding protein from yeast that bind to both silencer and activator elements. Cell 51:721-732.

62. Shore, D., D. J. Stillman, A. H. Brand, and K. A. Nasmyth. 1987. Identification of silencer binding proteins from yeast: possible roles in SIR control and DNA replication. EMBO J. 6:461-467.

63. Sikorski, R. S., and P. Hieter. 1989. A system of shuttle vectors and yeast hosts designed for efficient manipulation of DNA in Saccharomyces cerevisiae. Genetics 122:19-27.

64. Silve, S., P. R. Rhode, J. Campbell, and R. O. Poyton. Submitted for publication.

65. Simpson, R. T. 1990 . Nucleosome positioning can affect the function of a cis-acting DNA element in vivo. Nature (London) 343:387-389.

66. Strich, R. M., M. Wootner, and J. F. Scott. 1986. Mutations in $A R S 1$ increase the rate of simple loss of plasmids in Saccharomyces cerevisiae. Yeast 2:169-178.

67. Strienc, F., J. E. Bailey, and J. L. Campbell. 1985. Effect of ARSI mutations of chromosome stability in Saccharomyces cerevisiae. Mol. Cell. Biol. 5:1676-1684.

68. Sweder, K. S., P. R. Rhode, and J. L. Campbell. 1988. Purification and characterization of proteins that bind to yeast ARSs. J. Biol. Chem. 263:17270-17277.

69. Synder, M., A. R. Buchman, and R. W. Davis. 1987. Bent DNA at a yeast automonously replicating sequence. Nature (London) 324:87-89.

70. Thoma, F., L. W. Bergman, and R. T. Simpson. 1984. Nuclease digestion of circular TRPIARSI chromatin reveals positioned nucleosomes separated by nuclease-sensitive regions. J. Mol. Biol. 177:715-733.

71. Umek, R. M., and D. Kowalski. 1987. Yeast regulatory sequences preferentially adopt a non-B conformation in supercoiled DNA. Nucleic Acids Res. 15:4467-4480.

72. Verma, R., and J. L. Campbell. Identification and purification of $D B F-A$, a double-stranded DNA-binding protein from Saccharomyces cerevisiae. J. Biol. Chem., in press.

73. Walker, S. S., S. C. Francesconi, and S. Eisenberg. 1990. A DNA replication enhancer in Saccharomyces cerevisiae. Proc. Natl. Acad. Sci. USA 87:4665-4669.

74. Walker, S. S., S. C. Francesconi, B.-K. Tye, and S. Eisenberg. 1989. The OBF1 protein and its DNA-binding site are important for the function of an autonomously replicating sequence in Saccharomyces cerevisiae. Mol. Cell. Biol. 9:2914-2921.

75. Williams, J. S., T. T. Eckdahl, and J. N. Anderson. 1988. Bent DNA functions as a replication enhancer in Saccharomyces cerevisiae. Mol. Cell. Biol. 8:2763-2769. 